\title{
Exopolysaccharide and lactic acid bacteria: Perception, functionality and prospects
}

\author{
Vivek K. Bajpai', Irfan Ahmad Rather', Rajib Majumder'1, Shruti Shukla², \\ Abhinav Aeron ${ }^{3}$, Kangmin Kim 3 , Sun-Chul Kang4, R. C. Dubey5, \\ D. K. Maheshwaris, Jeongheui Lim ${ }^{6}$ and Yong-Ha Park ${ }^{1}$
}

\begin{abstract}
${ }^{1}$ Department of Applied Microbiology and Biotechnology, School of Biotechnology, Yeungnam University, Gyeongsan, Gyeongbuk 712-749, Korea; ' $D$ Department of Food Science and Technology, Yeungnam University, 280 Daehak-ro, Gyeongsan-si, Gyeongsangbuk-do 712-749, Korea; ${ }^{3}$ Division of Biotechnology, College of Environmental and Bioresource Sciences, Chonbuk National University, 79 Gobong-ro, Iksan-si 570-752, Joellabukdo (Jeonbuk), Korea; ${ }^{4}$ Department of Biotechnology, Daegu University, Gyeongsan, Gyeongbuk, 712-714, Korea; ${ }^{5}$ Department of Botany and Microbiology, Faculty of Life Sciences, Gurukul Kangri University, Haridwar 249-404, Uttarakhand, India; ${ }^{6}$ National Science Museum, Yuseong-gu, Daejeon, 305-705, Korea.
\end{abstract}

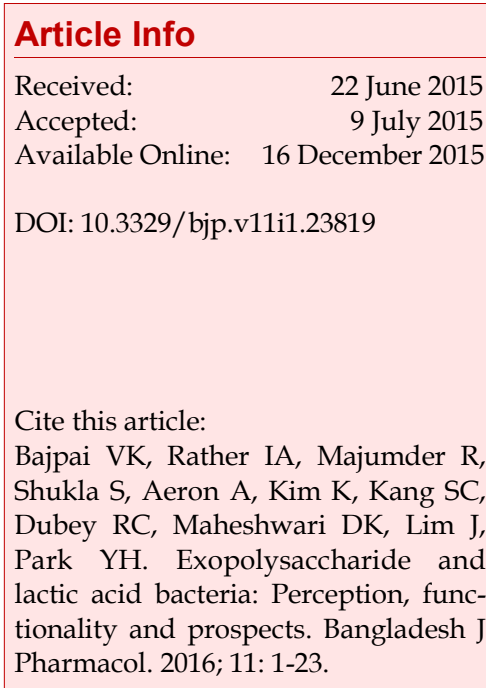

\begin{abstract}
Lactic acid bacteria exhibit the most effective potential to divert significant amount of fermentable sugars towards the biosynthesis of functional exopolysaccharide. Exopolysaccharides from lactic acid bacteria are receiving a renewed interest due to the claims of human health benefits. This review provides an update on multiple uses and production of exopolysaccharides with major emphasis on their chemical properties, characterization, and some other molecular strategies adopted for their genetics and biological tailoring to better understand the process of exopolysaccharide production along with their antiviral efficacy with multiple modes of action. Additionally, microbiological, biochemical, nutritional and biotechnological aspects of exopolysaccharide production have also been discussed. Moreover, appropriate suggestions have been made on lactic acid bacteria improvements, leading to enhanced production with advanced modification and production process that may contribute to the economic soundness of applications in food and pharmacological industries with this promising group of biomolecules.
\end{abstract}

\section{Introduction}

\section{Overview of exopolysaccharide}

Lactic acid bacteria are widely exploited in medicine, and traditional dairy products, as well as in biotechnological and industrial fermentation processes as a wellestablished starter culture (Park, 2001; Savadogo et al., 2004; Park et al., 2008; Kim et al., 2013a; Rather et al., 2013; Park et al., 2014). Lactic acid bacteria have shown a significant importance in health complications with increasing number of health beneficial microflora in the intestinal tract (Park et al., 2010), along with an ability to synthesize functional exopolysaccharides (Ricciardi and Clementi 2000; Seo et al., 2001; Savadogo et al., 2004; Kim et al., 2006; Kim et al., 2007). In addition, an important role of lactic acid bacteria has been noticed in the food fermentation, since lactic acid bacteria-derived fermented foods display increased rate of hygienic safety, storage stability and attractive sensory properties (Rather et al., 2014). Traditional differentiation of lactic acid bacteria species can be accomplished through their identification and detection by employing various 
molecular methods as potential alternatives in order to assess their quality control measures in dairy products (Bae et al., 2003; Kim et al., 2003; Savadogo et al., 2004; Koh et al., 2004; Bae et al., 2005).

Due to the versatile potentialily of microbial exopolysaccharides to work as a texturizer, viscosifer, emulsifier and syneresis-lowering agent, as well as due to their pseudo-plastic rheological behavior and water binding capacity, they have shown demanding Industrial need especially in food industry (Kodali et al., 2009). A wide range of different lactic acid bacteria produce different types of chemically-structured forms of exopolysaccharides. Since, there is no confirmed reports available on the harmful effects of lactic acid bacteria so far, they are classified as Generally Regarded as Safe (GRAS) microorganisms (Yadav et al., 2011). The microbial exopolysaccharides play a vital role to conceal the bacterial surface facilitating an adhesive interaction at the surface of other bacteria (Yadav et al., 2011). Moreover, they also work as a substance in the rhizosphere community for bacterial aggregation as well as environment protective agents (Badel et al., 2011). Since exopolysaccharides significant -ly contribute to the specific rheology and smooth textural properties of fermented and milk products, they have become major targets of ongoing research especially in food processing industry (Frengova et al., 2002; Habibi et al., 2011). Production of exopolysaccharidesis considered a unique feature of lactic acid bacteria in the formation of starters for fermented milk products. In addition, EPSs have shown number of health beneficial effects in human beings especially in the treatment of gastrointestinal, tumor and bowl diseases (Gibson and Rastall, 2003).

Lactic acid bacteria-derived exopolysaccharides, although produced in a very less amount in fermented yogurt, play a crucial role in improved smooth and creamy texture of yogurt, one of the very important aspects of yogurt quality. These EPSs have also shown industrial effectiveness in the development of improved quality low-milk-solid yogurt, low-fat yogurt, and cream yogurt with various health beneficial properties (Feldmane et al., 2013). In addition, various health beneficial attributes of lactic acid bacteria-derived exopolysaccharides have been confirmed previously either as non-digestible food fractions (Patel and Prajapati, 2013) or being natural candidates to treat cancer, ulcer and immune modulation along with their potent ability to reduce blood cholesterol levels (Madhuri and Prabhakar, 2014). Lactic acid bacteria and lactic acid bacteria-derived exopolysaccharides also have significant economic and therapeutic potential for the development of nutrient rich functional food products with prolonged human health beneficial effects.
Interestingly, exopolysaccharides may also play an important role by interacting with human immune system serving as vital component of functional foods as well as provide healing effects in bowel disease by working as prebiotics (Vinderola et al., 2006; Bello et al., 2001). A few selected lactic acid bacteria display exopolysaccharide production in the form of glucans or fructans by utilizing sucrose as sole carbon source through the action of glycosyl-transferase enzymes (Tieking et al., 2005). In addition, although, exopolysaccharides show potential ability to colonize dental surfaces by Streptococci, non-significant importance has been given on the relevance to the ecological niche of gastrointestinal biome lactic acid bacteria (Banas and Vickerman, 2003; Sims et al., 2011)

Lactic acid bacteria-derived exopolysaccharides in composition might exist as a single type of sugar monomer (homo-polysaccharides) or in the combination of several types of monomers (hetero-polysaccharides). However, variations in sugar composition, chain length, degree of branching, or sugar linkages in the exopolysaccharides produced by different lactic acid bacteria have been observed as leading factors, which assist in the termination of the rheological and healthpromoting potential of lactic acid bacteria-derived exopolysaccharides (Ruas-Madiedo et al., 2002). Based on the chemical composition of lactic acid bacteriaderived exopolysaccharides, they have been classified in two chemical classes, homo-exopolysaccharide and hetero-exopolysaccharide (Harutoshi, 2013). Homoexopolysaccharides are the chemical structures of single type of monosaccharide, whereas, hetero-exopolysaccharides contain regular repeating units of 3-8 different carbohydrate moieties synthesized from intracellular sugar nucleotide precursors (Ganzle et al., 2005). However, biosynthesis process of both homoand hetero-exopolysaccharides differs from each other. Synthesis of homo-exopolysaccharide occurs through the enzymatic reactions of glucansucrase or levansucrase by using sucrose (van Hijum et al., 2004), whereas, hetero-exopolysaccharide synthesis completes in four major steps involving sugar transportation, sugar nucleotide synthesis, repeating unit synthesis, and polymerization of the repeating units (de Vuyst and Degeest, 1999).

Generally exopolysaccharides are produced either in a bioreactor or in situ through proper down-stream processing for their further practical applications as a functional food additives and in fermentation purposes. Since lactic acid bacteria are often used in the preparation of fermented mixed starter cultures for dairy fermented food products, application of exopolysaccharides as bio-ingredients in food industry depends on the recovery rate and economic yield production (Sanchez et al., 2006). Lactic acid bacteria are the 
predominant microbiota and play an important role in natural fermentation of meat and vegetables and are used as mixed starters in controlled fermentation process (Sanchez et al., 2006). In addition, mesophilic lactobacilli bacteria as a secondary microbiota have also shown significant role in the development of unique flavor and texture of cheese products (Wouters et al., 2002).

Biotechnological advances have led to the discovery of lactic acid bacteria-derived biopolymers or exopolysaccharide molecules with confirmed evidences of industrial and medical usefulness to mankind. Enriched with biocompatibility, being GRAS and non-toxic ability of lactic acid bacteria-derived exopolysaccharides have made them a first-line choice in the treatment of various chronic diseases including tissue engineering, drug delivery system, and disease healing ability as compared to the plants and algal-based polysaccharides (Otero and Vincenzini, 2003). Reports have confirmed that a few selected biopolymers can be degraded in vivo, they might be possible alternatives to synthetic biopolymers for using in tissue replacement and controlled drug release strategies (Rehm, 2010). This overview provides recent advancements on the knowledge of functional properties of lactic acid bacteria-derived classified exopolysaccharides, their chemical nature, molecular characterization, genetic synthesis and applications in medical and industrial sector with specially emphasis on their future prospects.

\section{Classification and chemical composition of exopoly- saccharide}

The microbial exopolysaccharide from lactic acid bacteria can be divided into two major groups such as homoexopolysaccharides and hetero-exopolysaccharides. An overview on the classification of lactic acid bacteriaderived exopolysaccharides has been summarized in Figure 1. In microbial cells, hetero- and some homopolysaccharides are synthesized and secreted into the extracellular environment. Although synthesis of homopolysaccharide occurs outside the cells after specific enzymes are exuded (Donota et al., 2012). Homoexopolysaccharides consist of four sub-groups including a -D-glucans, $\beta$-D-glucans, fructans and poly-galactans (Harutoshi, 2013). The homo-exopolysaccharides, a-Dglucans such as dextrans produced from Leuconostoc mesenteroides subsp. mesenteroides and L. mesenteroides subsp. dextranicum, alternans from L. mesenteroides and mutans from Streptococcus mutants and S. sobrinus are mainly composed of $a-1,6$ and $a-1,3$-linked glucose molecules with variable degrees of branching at position 3 , although, they may also be present at position 2 or 4 however less frequently (de Vuyst and Degeest, 1999; Harutoshi, 2013). On the other hand, homoexopolysaccharides such as $\beta$-D-glucans produced by Pediococcus and Streptococcus species are composed of glucose molecules linked to $\beta-1,3$ residual position along with $\beta-1,2$ branching. Mono-polysaccharides, fructans produced from Streptococcus salivarius are linked to $\beta$-fructose molecules at $\beta-2,6$ residual position along with $\beta-2,1$-branching on $\mathrm{O} 1$ site. The polygalactans types of homo-exopolysaccharides are composed of repeating sugar units which are identical in their chemical structures and linked together with different glycosidic bonds. The hetero-exopolysaccharides are produced by the mesophilic and thermophilic lactic acid bacteria. The major mesophilic lactic acid bacteria include L. lactis sub-sp. lactis, $L$. rhamnosus, L. lactis sub-sp. cremoris, L. sakei, L. casei whereas L. delbrueckii sub-sp. bulgaricus, L. acidophilus, L. helveticus and $S$. thermophiles which are considered to be the major representatives of thermophlic lactic acid bacteria. Sugar linkage pattern of some of the selected lactic acid bacteria-derived exopolysaccharides has been given in Figure 2.

\section{Homo-exopolysaccharide}

The lactic acid bacteria have ability to produce exopolysaccharide either as an environmental secretion or cell adhered EPS in a capsular form (Harutoshi, 2013). Generally exopolysaccharides are classified into two major groups including homo-exopolysaccharide and hetero-exopolysaccharide. Homoexopolysaccharides are consisting of single type of monosaccharide such as $\alpha$-D-glucans, $\beta$-D-glucans, fructans, and polygalactans, whereas, heteroexopolysaccharides are formed of different types of monosaccharides including D-glucose, D-galactose, Lrhamnose, and their derivatives (Mayo et al., 2010; Harutoshi, 2013). Homo-exopolysaccharides possess differences with each other's due to various important factors such as the primary structural skeleton including pattern of chain bonds, brand structures and molecular weights. The most significant groups of lactic acid bacteria-derived exopolysaccharide are represented by a-glucans such as dextrans and mutans which are produced by L. mesenteroides and S. mutans, respectively; whereas fructans such as levan are produced by S. salivarius (Cerning, 1990). Dextran is generally produced from sucrose in L. mesenteroides sub-sp. Mesenteroides (Cerning, 1990). However, increased rate of salt components has shown negative effect on dextran formation in the growth medium during serial transformation. Moreover, Leuconostoc species such as L. amelibiosum can also produce dextran in the growth medium when supplemented with orange or tomato juice (Vuyst and Degeest, 1999). Generally the members of dextran family share a-1,6linkages with variable degree of branching at residual position of 2, 3 or 4 (Harutoshi, 2013).

A number of strains of Streptococcus species have shown the ability to form mutan, a homo exopolysaccharide glucan with a-1,3 linkages which differs from dextran 


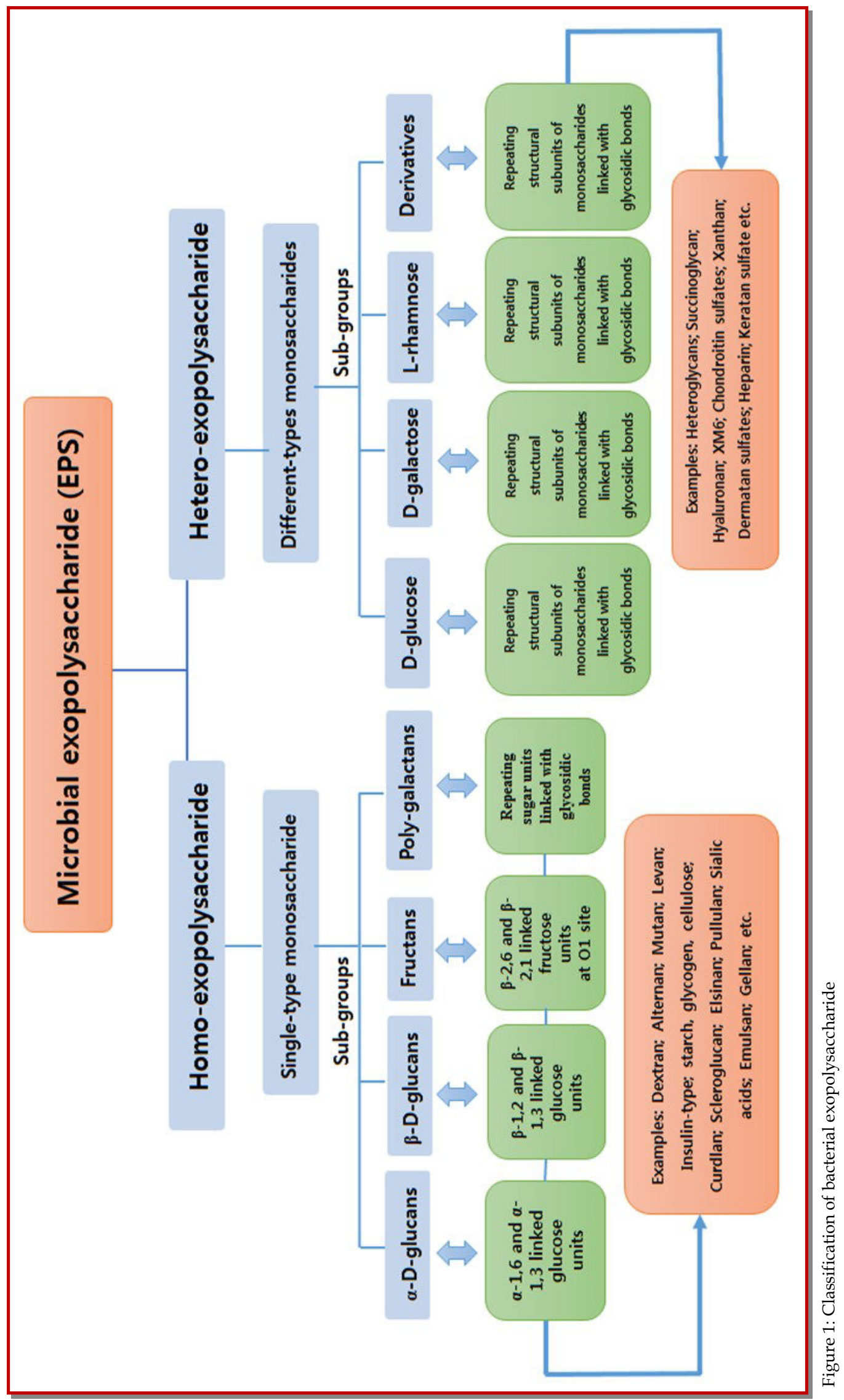




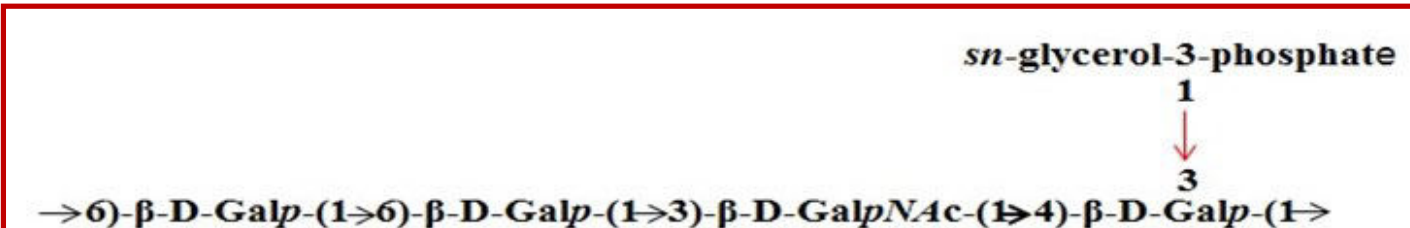

EPS from Lactobacillus paracasei

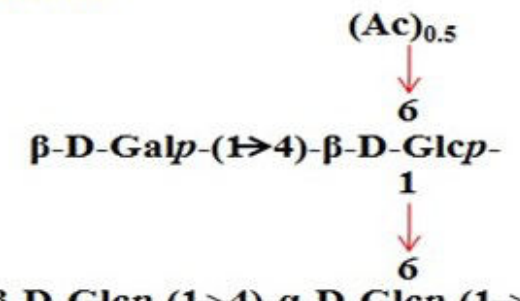

$\rightarrow 4)-\beta-D-G a l p-(1>4)-\beta-D-G I c p-(1 \rightarrow 4)-\alpha-D-G I c p-(1 \rightarrow$

EPS from Lactococcus lactis subsp. cremoris

sn-glycerol-3-phosphate $>4)-\alpha-L-R h a p$

(Ac) $)_{0.85}$

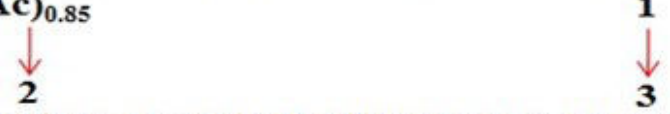

$\rightarrow 3)-\beta-L-R h a p-(1 \rightarrow 4)-\beta-D-G l c p-(1>4)-\alpha-D-G l c p-(1 \rightarrow$

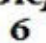

EPS from Lactobacillus sakei

1

B-D-Glcp

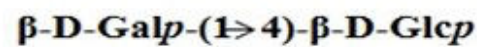

1

$\downarrow$

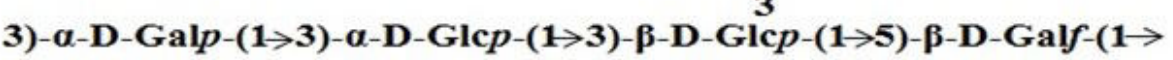

EPS from Lactobacillus helveticus

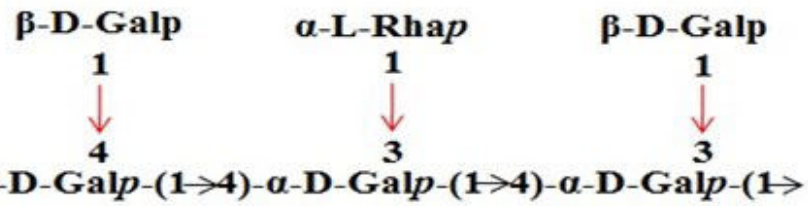

EPS from Lactobacillus delbrueckii subsp. bulgaricus

$\rightarrow 6)-\alpha-D-G a l p-(1>6)-\alpha-D-G l c p-(1>3)-\beta-D-G a l f-(1 \rightarrow 3)-\alpha-D-G l c p-(1 \rightarrow 2)-\beta-D-G a l f-(1 \rightarrow$

EPS from Lactobacillus rhamnosus

Figure 2: Sugar linkage pattern of various EPSs isolated form different lactic acid bacteria (LAB) [Gruter et al., 1993; Landersjo et al., 2001; Robijin et al., 1995; van Casteren et al., 2000; van Casteren, 2001; Yamamoto et al., 1995] 
being highly soluble in water as well as dextran possesses higher number of a-1,6 linkages (Cerning, 1990). Since water insoluble mutan helps to facilitate microorganisms to attach on teeth surface, it is highly consumed in dental cavities and dental caries. Another glucan homo-exopolysaccharide, an altrnan firstly isolated from L. mesenteroides NRRL B-1355 with distinctive physical attributes possesses $a-1,6$ and $a-1,3$ alternate linkage, making it to be a component of high water solubility and low viscosity potential for using at industrial purposes, especially in food industry as a low viscosity texturizer (Cote and Robyt, 1982; Harutoshi, 2013).

A fructan homo-exopolysaccharide, levan is produced in the growth medium utilizing sucrose as carbon source, which is composed of $\beta$-2,6-linked fructose units with $\beta$-2,1-linked branching (Harutoshi, 2013). For example, a fructan, insulin is also composed of $\beta-2,1$ linked fructose sugar units along with $\beta-2,6-$ linked branching. Previously S. salivarius, L. mesenteroides, and L. reuteri have shown the ability to synthesize homoEPS levan (Uchida, 1996). A homo-exopolysaccharide, fructan has also been reported to produce from $\mathrm{L}$. sanfranciscensis (Korakli et al.,2002). Chemical structures of some of the beneficial and industrial homoexopolysaccharides have been provided in Figure 3A.

\section{Hetero-exopolysaccharide}

The biopolymer members of hetero-exopolysaccharide show diverse range of chemical differentiation among each other's, composed of repeating units of mainly Dglucose, D-galactose, and L-rhamnose (Harutoshi, 2013). The chemical composition and repeating structural subunits of monosaccharides used to form a hetero-EPS polymer do not mean to confer species specificity. Although exceptions exist such as a Lactobacillus species, L. kefiranofaciens subsp. Kefiranofaciens, isolated from a fermented food product Kefir in North Caucasus, were able to produce enormous amount of hetero-exopolysaccharides (De Vos et al., 2009; Harutoshi, 2013). A number of microbial species such as Streptococcus thermophilus, Lactococcus lactis, L. delbrueckii, and Lactobacillus helveticus have been well recognized with an ability to produce heteroexopolysaccharides (Mozzi et al., 2006) In addition, lactic acid bacteria of homo-fermentative nature are well known for their ability to produce hetero-EPS, whereas, a hetero-fermentative strain L. fermentum has been found to produce exopolysaccharide with confirmed chemical nature determination (Leo et al., 2007). Although previously presence of inadequate production of hetero-exopolysaccharides has been confirmed in L. brevis and L. buchneri in the growth medium containing glucose or sucrose as carbon sources, no results were reported on the origin (Figueroa et al., 1995).
In general, the lactic acid bacteria have produced a wide variety of hetero-exopolysaccharides, however they have shown wide range of variations. A few bacterial isolates such as $S$. thermophiles, L. lactis sub-sp. cremoris, L. delbrueckii sub-sp. bulgaricus, L. casei and L. plantarum found to produce 50-350, 80-600, 60-150, 50-60 and about $140 \mathrm{mg} /$ liter of hetero-exopolysaccharide (Tallon et al., 2003; Tsuda and Miyamoto, 2010; Harutoshi, 2013). The maximum amount of exopolysaccharide recovery has been noticed for $L$. rhamnosus RW-9595 and L. kefiranofaciens WT-2B by 2,275 and 2,500 mg/liter, respectively (Maeda et al., 2004). Lactic acid bacteria have shown less ability on exopolysaccharide production than the microorganisms of industrial importance such as Xanthomonas campestris with about xanthan exopolysaccharide production of 30 -50 g/liter (de Vuyst and Degeest, 1999; Harutoshi, 2013). However, in situ exploitation has been successfully achieved for exopolysaccharides production from lactic acid bacteria, making them to be the candidates of choice for enhanced production of exopolysaccharides with higher yields, and their practical applications in food, pharma and dairy industries. Chemical structures of some of the beneficial hetero-exopolysaccharides have been given in Figure 3B.

\section{Molecular characterization of exopolysaccharide}

Molecular characterization of exopolysaccharides requires a complete information of molecular mass and identification of absolute configuration and composition of monomers leading to a final characterization of any polysaccharide molecule along with a linkage monomer pattern. Now-a-days, several analytical and spectral techniques are available to determine the molecular mass of any polysaccharide molecule. Previously size exclusion chromatography based on refractive index and retention time has been successfully used to determine the molecular mass of various polysaccharide molecules (Nichols et al., 2005). According to Williams et al., (1992), polysaccharide compounds are eluted very close to the limit of stationary phase during exclusion and represent very high molecular mass moieties. Application of combination detector which uses light scattering device to measure the molecular mass, can be able to determine molecular mass of polysaccharide molecules with significant accuracy (Law et al., 2001). In addition, application of various chromatographic methods have provided trustworthy results on the determination of chemical composition of polysaccharide monomers, among them methanolysis and per-trimethylsilylation have proved to be the significant steps for the processing of polysaccharide monomer samples which can be analyzed either by gas-chromatography and mass spectrometry or gas-liquid chromatography. Besides, analytical approach of methylation and nuclear magnetic resonance techniques have been successfully 

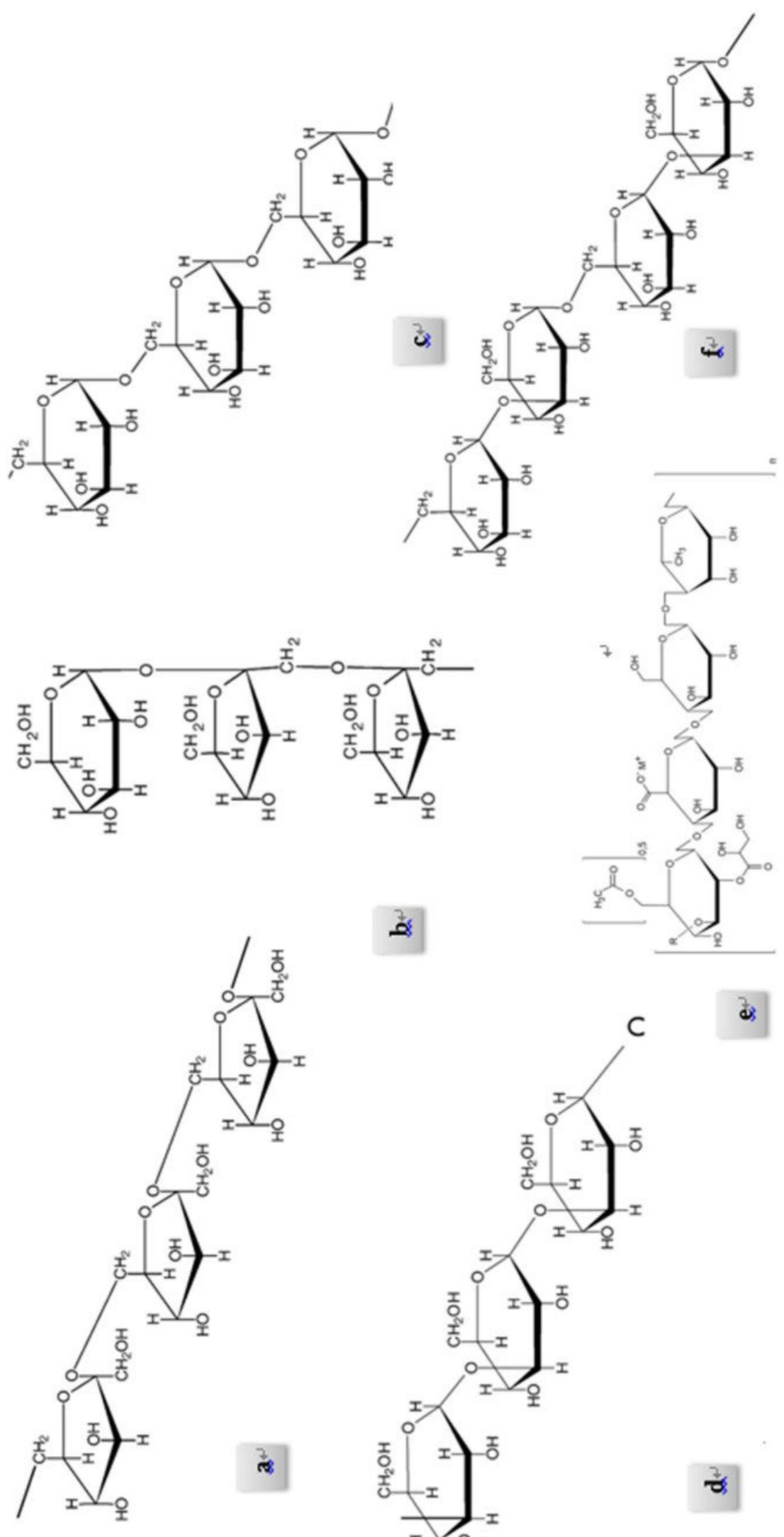

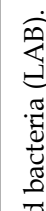

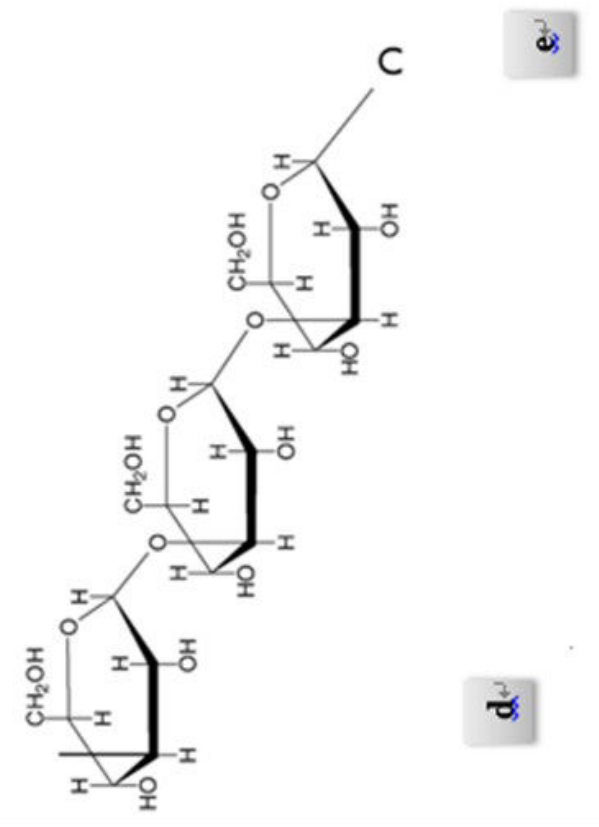




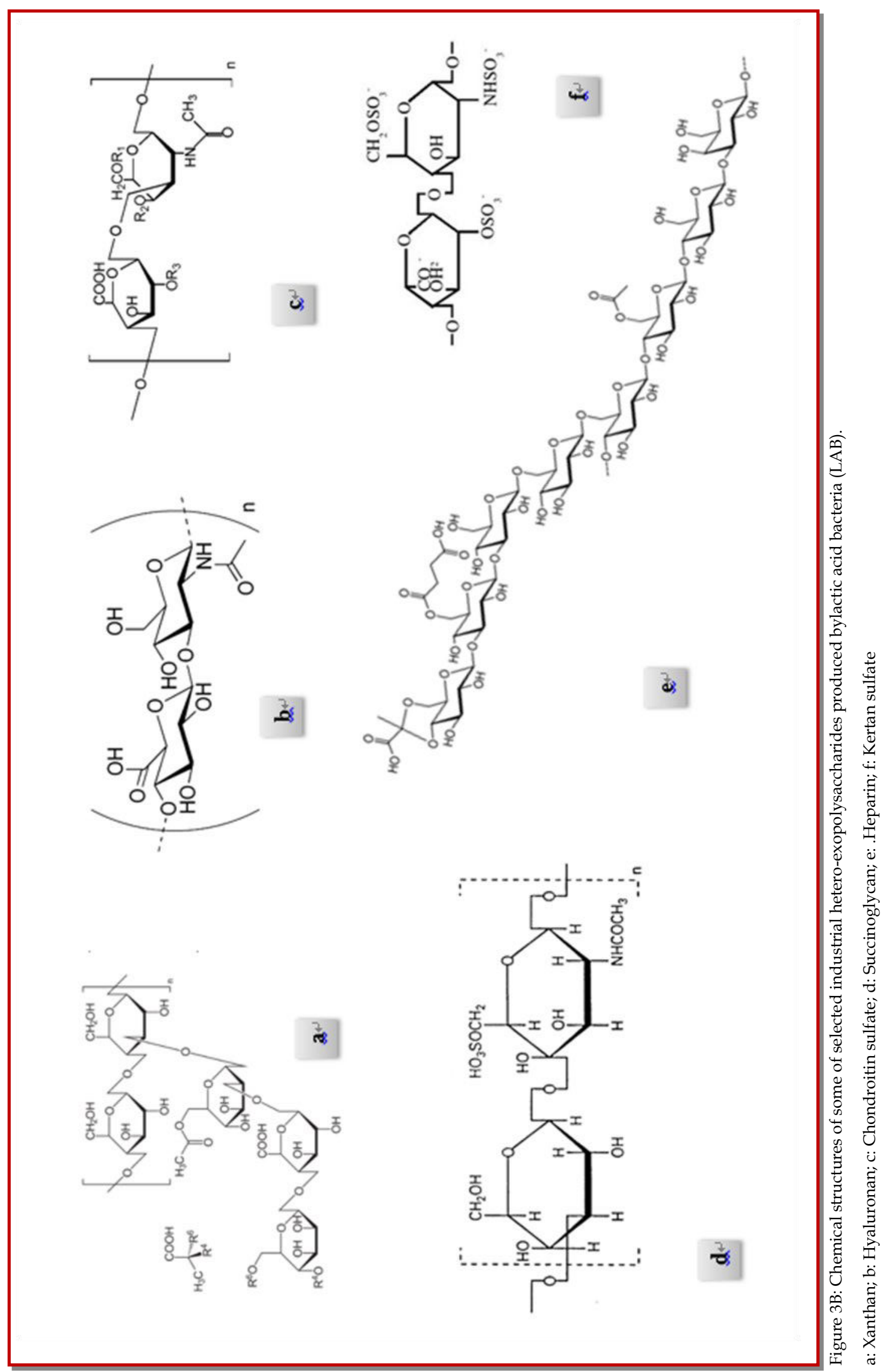


used to determine the linkage pattern of polysaccharide monomers (Le Costaouec et al., 2012). In the current scenario of molecular mass and spectroscopic data analysis, nuclear magnetic resonance techniques have provided most accurate data for complex polysaccharide molecules (Duus et al., 2000).

It has been reported that two-dimensional nuclear magnetic resonance spectroscopic technique has been successfully able to determine the primary chemical structure of exopolysaccharides of microbial origin (Leeflang et al., 2000). Application of known spectroscopic techniques is gaining more importance in the field of chemical structure analysis along with an additional efforts on to develop more advanced techniques for the easy and accurate determination of large molecular mass carbohydrate or polysaccharide molecules. In this regard, spin diffusion technique, a complement to the hetero nuclear multiple bond correlation, has provided positive results on the determination of linkage pattern of exopolysaccharide monomers (Vincent and Zwahlen, 2000). Recently suggestions have been made on the use of deuterium-induced differential isotope shifts to analyze the linkage pattern of exopolysaccharides monomers which can be a good substitute to twodimensional nuclear magnetic resonance technique and shaped pulses since these techniques result in the deletion of methylation step, leading to direct inspection of nuclear magnetic resonance of polysaccharide complex molecules (Navarini et al., 2001; Bendiak, 2002). In general, analysis and differentiation of different exopolysaccharides in various taxa of different groups of lactic acid bacteria by traditional and conventional methods assess the number of monosaccharides present in the repeating backbone units of oligosaccharide molecules which reflect the sugar residual numbers in the main oligosaccharide chain. However, a macroscopic identification can assist to determine the similarity among the variety of exopolysaccharides based on the similar structural writing pattern and set of rules for presenting exopolysaccharide structures.

\section{Genetics and biological synthesis of exopolysaccha- ridein lactic acid bacteria}

Lactic acid bacteria have potent ability to synthesize varied classes of polysaccharides assisting them to construct essential components of cell wall. Lactic acid bacteria synthesize polysaccharides using various known biosynthetic mechanisms correlated with cell wall component mechanisms (Welman and Maddox, 2003). The functional properties and biosynthetic ability of bacteria specially cell wall components were reviewed previously. In general, biosynthesis of exopolysaccharide is an energy-dependent process which utilizes one mole of adenosine triphosphate leading to conversion of each hexose substrate molecule to hexose phosphate followed by the utilization of high energy phosphate bond for the biosynthesis of each nucleotide sugar molecules. Further, this process requires another one mole of adenosine triphosphate energy, needed for the phosphorylation of the lipid carrier and for the transportation and polymerization of polysaccharide molecule. Since lactic acid bacteria have ability to generate energy in limited amount, this may result in the limited production of exopolysaccharide by lactic acid bacteria (de Vuyst and Degeest, 1999). However, production of exopolysaccharide is directly dependent on the growth of bacterial cells and can be well explained by the combined chemistry of cell growth parameters and their ability on exopoly-saccharide biosynthesis (Cerning et al., 1992).

The exopolysaccharide biosynthesis represents a very complexprocess involving the functional ability of number of genes assisting in the EPS biosynthesis. These exopolysaccharide related genes of plasmid and chromosomal regions specifically in mesophilic and thermophilic lactic acid bacteriasuch as Lactococcus, Streptococcus and Lactobacilli encode various enzymes and proteins, and importantly participate in the exopolysaccharide biosynthesis (Van Kranenburg et al., 1997; de Vuyst and Degeest, 1999). Genetic analysis of $S$. thermophiles Sfi6 resulted in the identification of exopolysaccharide locus with a $15.25 \mathrm{~kb}$ region which encoded 16 open readings to different lactic acid bacteria (Lamothe et al., 2002; Stingele et al.,1996). The orientation of gene cluster was unidirectional and each gene was transcribed as single mRNA (Jolly et al., 2001). However, mesophilic isolates of lactic acid bacteria have shown instability on exopolysaccharide production due to the unstable nature of plasmid region genes which specially encode various enzymes for exopolysaccharide biosynthesis in mesophilic lactic acid bacteria. On the other hand, deletions and genetic re-establishments in lactic acid bacteria may affect the exopolysaccharide production ability of thermophilic bacteria significantly. Moreover, a number of other housekeeping genes encoding various enzymes needed for the formation of sugar nucleotides also play an important role in the molecular biosynthesis of exopolysaccharide in lactic acid bacteria.

An overview on biosynthetic ability of exopolysaccharides by lactic acid bacteria has been given in Figure 4. As demonstrated, the biosynthesis of glucose1-phosphate results in the production of UDP-glucose, UDP-galactose, and dTDP-rhamnose nucleotide sugars which are attached to phospholipids on the lipid carrier and assemble into sugar units. Further, transfer of sugar nucleotides diphospho-precursors to a carrier lipid results in the formation of basic repeat unit, where lipid carrier plays a pivotal role on assembling of repeating sugar units (Kleerebezem et al., 1999). In addition, analysis of lipid-linked oligosaccharides (Peant et al., 2005) has confirmed that biosynthesis of heteropolysaccahirdes begins with the formation of EPS monomers such as intracellular exopolysaccharide 


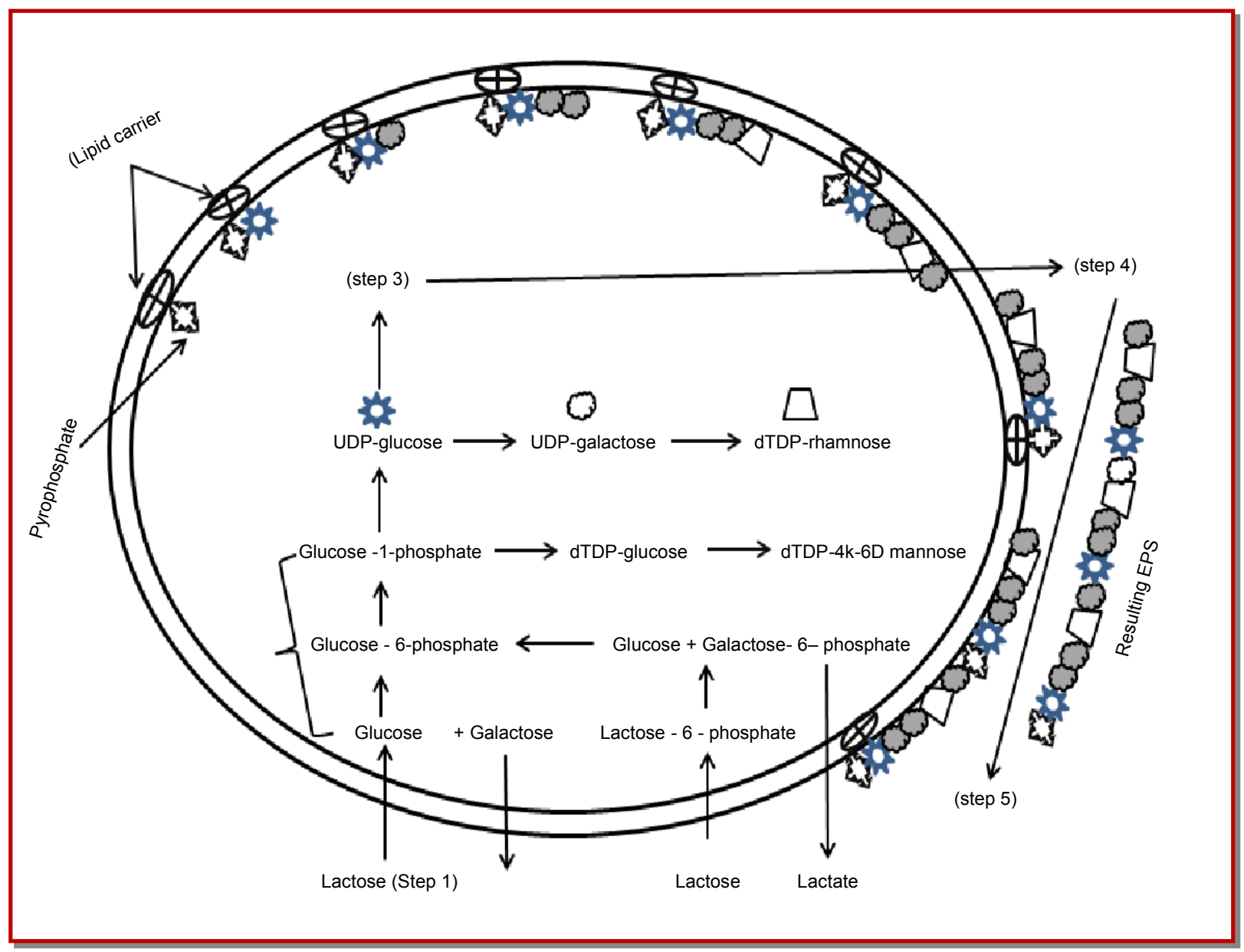

Figure 4: Biosynthesis of exopolysaccharide (EPS) in lactic acid bacteria (LAB).

$1^{\text {st }}$ step: Transportation of sugar into the cytoplasm; $2^{\text {nd }}$ step: Synthesis of glucose-1-phosphate; $3^{\text {rd }}$ step: Sugar nucleotides synthesisand polymerization into EPS subunit; $4^{\text {th }}$ step: Export out of the cytoplasm; $5^{\text {th }}$ step: Polymerization and detachment of EPS [Kleerebezem et al., 1999]

precursors, uridine-59-diphosphate-galactose, uridine59-diphosphate-glucose and deoxythymidine diphosphate-rhamnose, leading to the biosynthesis of most repeating units (Peant et al., 2005). Role of different exopolysaccharide encoding genes has been confirmed previously in various lactic acid bacteriaat genus and species level (Broadbent et al., 2003; Jolly et al., 2001, 2002; van Kranenburg et al., 1997). Generally microorganisms produce number of substances as a mixture of polymers which are synthesized through specific genes located on gene cluster (Hay et al., 2010; Orr et al., 2009; van Kranenburg et al., 1999). Although vast majority of genetic information is available on xanthan, related information on other types of exopolysaccharides is rare. The exopolysaccharide biosynthesis of xanthan is controlled by gum genes in Xanthomonas campestris located on a single gene cluster of $12 \mathrm{~kb}$ (Vorholter et al., 2008), where nucleotide sugars of uridine-59-diphosphate-glucose, uridine-59diphosphate-glucoronate and guanosine-59diphosphate-mannose make the repeating units of xanthan, leading to enhanced production of xanthan exopolysaccharide (Vorholter et al., 2008). In addition, gum genes (D, H, I, K, M) also encode the biosynthesis of glycosyltransterase (van Kranenburg et al., 1999; Vorholter et al., 2008). Recently it has been reported that in Pseudomonas aeruginosa, 12 gene cluster in a single operon encodes the production of alginates (Hay et al., 2010). However, a gum gene (algC) involved in EPS production was found to locate on chromosomal region which encodes phosphomannomutase (Hay et al., 2010). Although limited information is known on molecular mechanism of exopolysaccharide biosynthesis, genetic establishments such as genes encoding regulation, repeating-unit assembly, chainlength determination, polymerization and exportation play a very important role in exopolysaccharide biosynthesis especially in Gram-positive bacteria (de Vuyst and Degeest, 1999; Peant et al., 2005; Jolly et al., 2001). Way of organization of exopolysaccharideregulation genes in some of the selected lactic acid bacteriahas been illustrated in Figure 5 . 


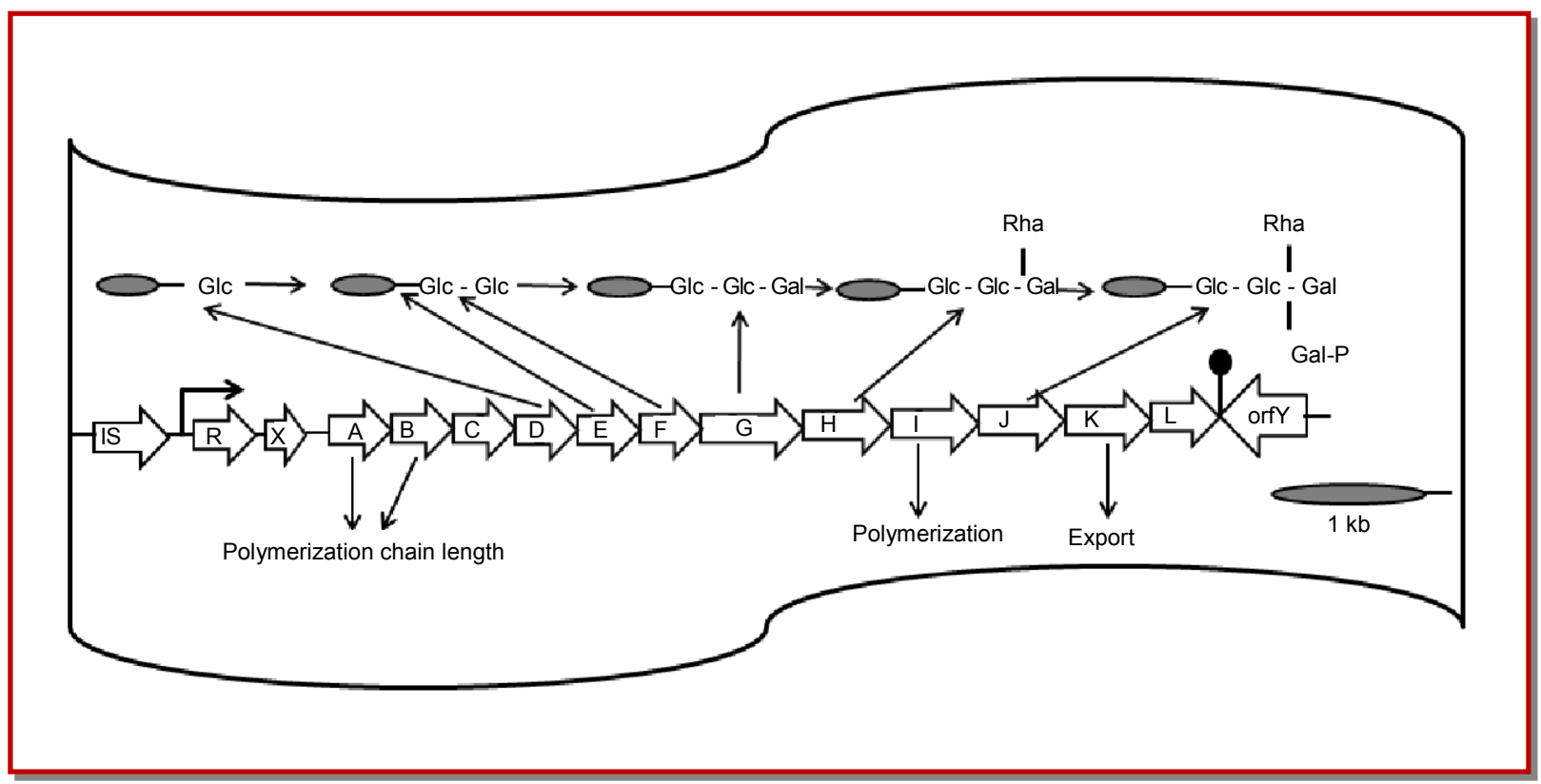

Figure 5: Systematic way of organization of exopolysaccharide(EPS) genes in some LAB species (Lactococcus lactis) [Van Kranenburg et al., 1997; Welman andMaddox, 2003]

It is obvious to say that in-depth studies are certainly required to provide innovativeinsights on the exopolysaccharide biosynthesis pathways and theirgenetic regulation for the enhanced production of quality-rich EPS (Welman and Maddox, 2003). Multitude of combined experimental skills with an integrated molecular approach on metabolic biosynthetic pathway will probably require in order to bring a significant production rate of exopolysaccharide from lactic acid bacteria. In addition, in silico production, genetic modifications, gene expression level studies, molecular modeling and application of advanced techniques may also help to enhance on exopolysaccharide biosynthesis from lactic acid bacteria (Welman and Maddox, 2003). Since lactic acid bacteria represent a vast group of bacteria with multitude of industrial applications, successful exploitation of these group of bacteria in terms of their potent ability on exopolysaccharide biosynthesis and their various functional and health beneficial effects will certainly lead to innovative industrial and pharmacological applications.

Industrial and pharmacological applications of exopolysaccharide

Microbial exopolysaccharides, molecules of diverse chemical composition,have shown multitude of functional and health beneficial effects with enormous range of applications in food, cosmetic, agronomy and pharmaceutical industries. Since lactic acid bacteriabased products ascertain various functional properties, application of EPS can be exploited in the food industry with reliable amount of yields and recovery rate (Patel et al., 2010; Patel et al., 2012). Moreover, production of exopolysaccharides from lactic acid bacteria can be economically feasible if production parameters and other factors which affect the exopolysaccharide production could be optimized such as cheaper substrates and cost-effective fermentation conditions (Patel et al., 2010; Patel et al., 2012). A detailed description on recent progress pertaining to various functional and health beneficial properties of lactic acid bacteria and lactic acid bacteria-based exopolysaccharides has been summarized in Table I.

A number of importantapplicationsof lactic acid bacteria-based exopolysaccharides have been developed for their commercial exploitation especially with health benefit purposes and considerable amount of progress has been made for discovering novel types of microbial exopolysaccharides for industrial purposes (Tieking et al., 2005; Kumar and Modi, 2009). Moreover, lactic acid bacteria-basedexopolysaccharides have shown remarkably positive effects on gut health, as well as exhibit antitumor effect, cholesterol lowering effect, and immunomodulatory effect (Madhuri and Prabhakar, 2014). The exopolysaccharide derived from Bacillus licheniformis was found to diminish the replication of herpes simplex virus-2in human peripheral blood mononuclear cells exhibiting antiviral effect in vivo. In addition, non-digestible oligosaccharides as prebiotics have also been found to stimulate the growth and activity of health beneficial bacteria including Bifidobacteria and Lactobacilli in the colon, thereby show health benefits in human host (Harutoshi, 2013). Also exopolysaccharides can facilitate the colonization of gastrointestinal tract by lactic acid bacteria and Bifidobacteria due to their prolong survival ability in gastrointestinal tract. Besides, exopolysaccharides 
Table I

List of different EPSs isolated from LAB strains showing various functional properties

\begin{tabular}{|c|c|c|c|c|}
\hline Name of EPS & Source strain & Structure & $\begin{array}{l}\text { Application and biological } \\
\text { importance }\end{array}$ & References \\
\hline Reuteran & $\begin{array}{l}\text { Lactobacillus reuteri LB } \\
121 \mathrm{Lb} \text {. reuteri ATCC } \\
55730 \mathrm{Lb} \text {. reuteri } 35-5\end{array}$ & $\begin{array}{l}\text { a-1,4 linkage, also a-1,6 } \\
\text { glycosidicbonds }\end{array}$ & Used in bakery & $\begin{array}{l}\text { Tieking and Ganzle, } \\
2005 \text { Kralj et al., } 2005\end{array}$ \\
\hline Inulin & $\begin{array}{l}\text { Lb. johnsonii NCC } 533 . \\
\text { Streptococcus mutans } \\
\text { JC2, Leuc. citreum } \\
\text { CW28 Lactobacillus } \\
\text { reuteri } 121\end{array}$ & $\beta-1,2$ glycosidic bonds & $\begin{array}{l}\text { Prebiotics, nourish gut } \\
\text { mucosal cells and inhibit } \\
\text { pathogens, targeted drug } \\
\text { delivery against colon } \\
\text { cancer, substitute of fat in } \\
\text { food products }\end{array}$ & $\begin{array}{l}\text { Buchholz and Seibel, } \\
2008 \text { Sartor , } 2004\end{array}$ \\
\hline Kefiran & $\begin{array}{l}\text { Lb. kefirgranum } L b . \\
\text { parakefir } L b . \text { kefir } L b . \\
\text { delbrueckii subsp. } \\
\text { bulgaricus }\end{array}$ & $\begin{array}{l}\text { Glucose and galactose } \\
\text { monomers form variable } \\
\text { acidic bonds }\end{array}$ & $\begin{array}{l}\text { Improve viscoelastic prop- } \\
\text { erties of acid milk gels, } \\
\text { antimicrobial and wound } \\
\text { healing properties, ability } \\
\text { to lower blood pressure } \\
\text { and cholesterol in serum, } \\
\text { capacity to retard tumor } \\
\text { growth, enhance immunity } \\
\text { of gut }\end{array}$ & $\begin{array}{l}\text { Micheli et al., } 1999 \\
\text { Medranoet al.,2008 } \\
\text { Vinderola et al., } 2006\end{array}$ \\
\hline New EPS & Lb. johnsonii & $\begin{array}{l}\rightarrow 6) \text { - } \alpha-D-G a l p-(1 \rightarrow 6)-\alpha-D- \\
\text { Glcp- }(1 \rightarrow 3)-\beta-D-G a l f- \\
(1 \rightarrow 3)-\alpha-D-G l c p-(1 \rightarrow 2)-\beta- \\
\text { D-Galf- }(1 \rightarrow\end{array}$ & Immune-reactivity & $\begin{array}{l}\text { Gorska-Fraczek et al., } \\
2013\end{array}$ \\
\hline OLL1073R-1 & $\begin{array}{l}\text { L. delbrueckii sp. bul- } \\
\text { garicus }\end{array}$ & - & $\begin{array}{l}\text { Anti-IFV IgA, IgG1 in BAL } \\
\uparrow \mathrm{NK} \text { cell activity } \uparrow \\
\text { (IFV = influenza virus; } \\
\text { BALF = bronchoalveolar } \\
\text { lavage fluid) }\end{array}$ & Nagai et al., 2011 \\
\hline $\begin{array}{l}\text { Novel hetero } \\
\text {-EPS }\end{array}$ & S.phocae PI80 & $\begin{array}{l}\text { Larger number of }(\mathrm{O}-\mathrm{H}) \text {, } \\
(\mathrm{C}=\mathrm{O}),(\mathrm{C}-\mathrm{H}) \text { stretching } \\
\text { frequency and carboxyl } \\
\text { group. Combination of } \\
\text { arabinose, fructose and } \\
\text { galactose monomers }\end{array}$ & $\begin{array}{l}\text { Emulsifying and flocculat- } \\
\text { ing activities, antioxidant, } \\
\text { anti-biofilm }\end{array}$ & Kanmani et al., 2011 \\
\hline$\beta$-glucan & $\begin{array}{l}\text { Pediococcus damnosus } \\
2.6\end{array}$ & $\begin{array}{l}\text { Dglcose monomers linked } \\
\text { by } \beta \text {-glycosidic bonds }\end{array}$ & Starter culture & $\begin{array}{l}\text { Martensson et al., } \\
2000\end{array}$ \\
\hline New EPS & $\begin{array}{l}\text { Leuconostoc sp. CFR } \\
2181\end{array}$ & $\begin{array}{l}a(1 \rightarrow 6) \text { linkage Glucose, } \\
\text { rhamnose and arabinose }\end{array}$ & Starter culture & $\begin{array}{l}\text { Vijayendra and Babu, } \\
2008\end{array}$ \\
\hline Glucan & Lactococcus lactis 1.8 & Capsular & - & $\begin{array}{l}\text { Van der Meulen et al., } \\
2007\end{array}$ \\
\hline$\alpha$ and $\beta$-glucans & Lb. brevis G-77 & - & Starter culture & \\
\hline Glucan & Leuc. citreum 1.10 & Non-capsular & - & $\begin{array}{l}\text { Van der Meulen et al., } \\
2007\end{array}$ \\
\hline Hetero-EPS & Lb. curvatus 10 & $\begin{array}{l}\text { Galactosamine, galactose, } \\
\text { glucose }\end{array}$ & - & $\begin{array}{l}\text { Van der Meulen et al., } \\
2007\end{array}$ \\
\hline Homo-EPS-3 & Lb. plantarumLP6 & $\begin{array}{l}71.3 \% \text { carbohydrate con- } \\
\text { tent }\end{array}$ & Antioxidant & Li et al., 2013 \\
\hline
\end{tabular}




\begin{tabular}{|c|c|c|c|c|}
\hline \multicolumn{5}{|c|}{ Table I (Cont.) } \\
\hline \multicolumn{5}{|c|}{ List of different EPSs isolated from LAB strains showing various functional properties } \\
\hline Name of EPS & Source strain & Structure & $\begin{array}{l}\text { Application and biological } \\
\text { importance }\end{array}$ & References \\
\hline Neutral EPS & $\begin{array}{l}\text { Lb.fermentum } \\
\text { TDS030603 }\end{array}$ & $\begin{array}{ll}\text { D-glucose and } & \text { D- } \\
\text { galactose, terminal } & \text { D- } \\
\text { Glcp, 3-substituted } & \end{array}$ & - & Gerwig et al., 2014 \\
\hline & & $\begin{array}{l}\text { D-Glcp, 2,3-disubstituted } \\
\text { D-Glcp, and 6-substituted } \\
\text { D-Galp }\end{array}$ & & \\
\hline EPS & Lb. rhamnosus KL37B & $\begin{array}{l}\text { Non-saccharide repeating } \\
\text { units }\end{array}$ & - & $\begin{array}{l}\text { Gorska-Graczek et al., } \\
2011\end{array}$ \\
\hline Kefiran & LAB & $\begin{array}{l}\text { D-glucose (Glc), D- } \\
\text { galactose (Gal) and D- } \\
\text { xylose }(X y l)\end{array}$ & - & Zajsek et al., 2013 \\
\hline Neutral EPS & Lb. johnsonii 142 & $\begin{array}{l}\rightarrow 3) \text {-a-D-Galp- }(1 \rightarrow 3)-\beta \text {-D- } \\
\text { Glcp- }(1 \rightarrow 5)-\beta-D-G a l f- \\
(1 \rightarrow 3) \text { - } \alpha-D-G a l p-(1 \rightarrow 3) \text { - } \alpha- \\
\text { D-Galp- }(1 \rightarrow\end{array}$ & - & Gorska et al., 2010 \\
\hline Glucan & Weissella cibaria MG1 & $\begin{array}{l}\text { e }(a-1,6) \text { and glucooligo- } \\
\text { saccharide }\end{array}$ & Adjunct culture in cheese & Lynch et al., 2014 \\
\hline EPS & Lb. casei $\mathrm{C} 12$ & Heteropolysaccharide & Adjunct culture in cheese & \\
\hline Glucan & Lb. reuteri ff $2 \mathrm{hh} 2$ & $\begin{array}{l}\text { homopolysaccharide } \\
1,6 \text { and } a-1,4) \text { and }\end{array}$ & Adjunct culture in cheese & \\
\hline & & fructooligosaccharide & & \\
\hline Glucan & Lb. reuteri $\mathrm{cc} 2$ & $\begin{array}{l}\text { Homopolysaccharide } \\
1,6 \text { and } \alpha-1,4)\end{array}$ & Adjunct culture in cheese & \\
\hline & & and fructooligosaccharide & & \\
\hline
\end{tabular}

render unique features including alleviation of lactose intolerance, immunity enhancement against harmful pathogens and reduction of mutagenic enzymes such as $\beta$-glucuronidase, nitroreductase and chologlycine hydrolase (de Roos and Katan, 2000). In addition to the ability of exopolysaccharides as food additives, they have shown improved specificity of drug release in the treatment of colon cancer. EPSs which serve as substrates for colon microflora, have also been utilized successfully in drug conjugation as well as coating and matrix agents (Vandamme et al., 2002). It has been reported that few selected exopolysaccharides have been found to display B-cell mitogen like activity along with an ability to modify the functions of macrophages and splenocyte (Kitazawa et al., 2000). An exopolysaccharide derived from L. johnsonni isolated from intestinal tract of mice displayed broad range of immunity reactions (Gorska-Fraczek et al., 2013). Bifidobacteria and Lactobacilli conferred to be as health promoting bacteria have potential ability to inhibit pathogenic bacteria and stimulate host immune system dramatically (Mitsuoka, 1992).

In general, microflora of gastrointestinal tract consist of about $10^{14}$ colony forming unit/g of different types of both pathogenic and beneficial bacteria with diverse range of composi-tional variations along the gastrointestine (Mitsuoka, 1992). Equilibrium of gastrointestinal microflora signifi-cantly affect the host health in terms of smooth bowl moment, tympanites flatulence and nutrient absorption (Harutoshi, 2013). A number of factors might have detrimental effect on this microflora equilibrium such as a biotic or biotic stress, antibiotic consumption, infection, food poisoning, and the natural ageing process. However, to diminish this detrimental effect and to maintain the proper growth and biological activities of these beneficial microflora, supply of specific ingredients in consumable food can provide significant improvement (Harutoshi, 2013).

Further, levans, group of fructans, have been used in food, pharma and cosmetic industries with special emphasis in food industry as a food and feed additives when used with prebiotics (Kang et al., 2009). Levans and dextrans have also been found to exhibit hypocholestrolemic effect (Kang et al., 2009). In addition, alginates have been used as thickening agents in food industry (Remminghorst et al., 2009). Also xanthan has showed its potent ability being used as a viscosifer, thickener, emulsifier or stabilizer in the food industry (Becker and Vorholter, 2009). Exopolysaccharides of microbial origin have been known for their versatile rheological properties which make them suitable candidates for using in food industry especially in variety of yoghurts with a high purity rate (Tieking and Ganzle, 2005). As reported previously, fructose- 


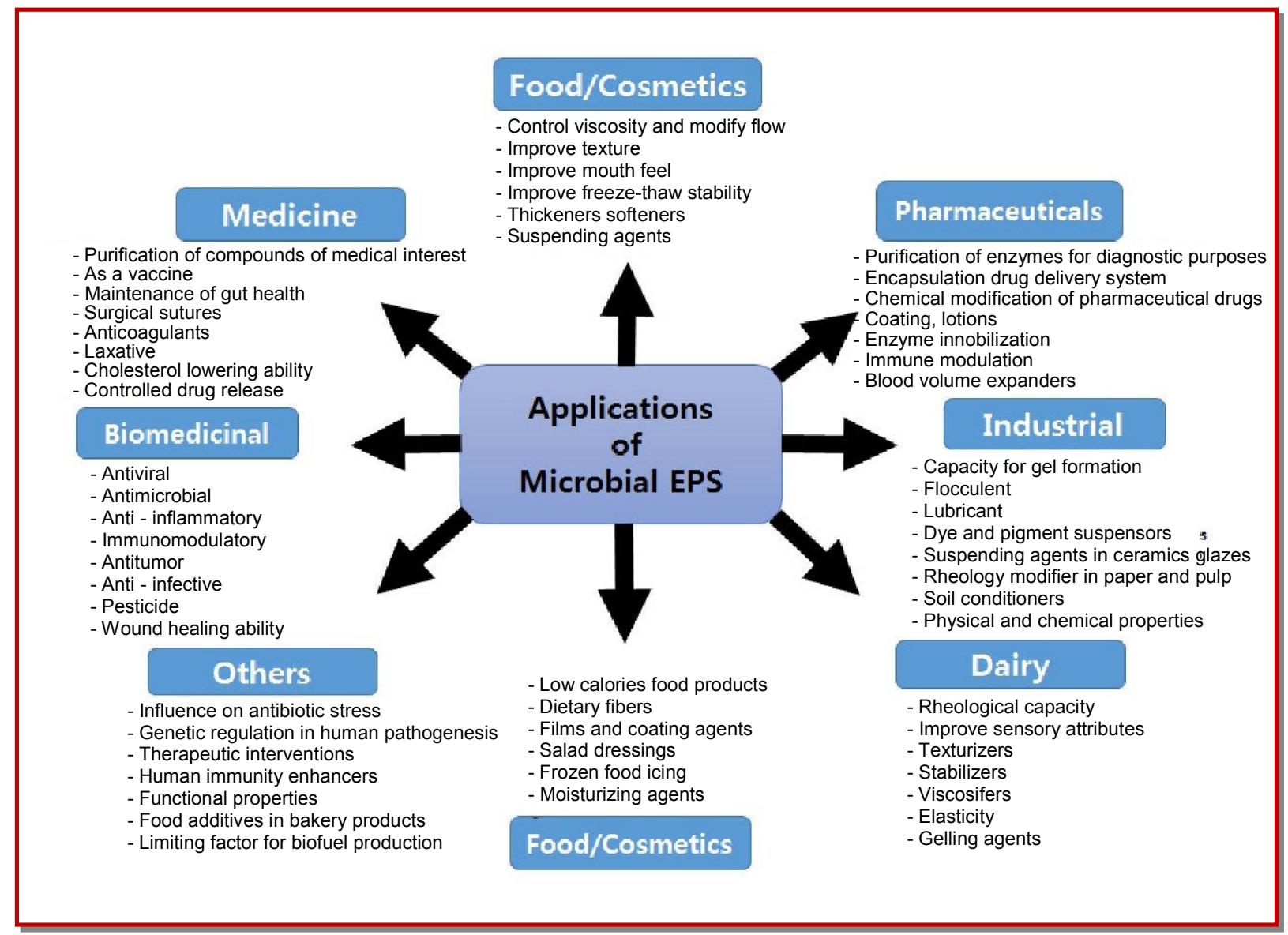

Figure 6: Multifarious applications of microbial exopolysaccharides (EPS) in various industries

oligosaccharides, low calorie and low sugar components have various applications in food industry with a status non-carcinogenic (Yun, 1996). Also based on the prebiotic properties of inulin and fructose-oligosaccharides, they have been used in food industry (Rhee et al., 2002). Moreover, polymers of fructose, fructans have significant role in plant cellular stress tolerance by protecting membrane stabilization (Oliver et al., 2001). In addition, dextran has ability to protect the producer strain during starvation or adverse conditions such as an alkaline or acidic state (Kim et al., 2007). Since fructose-oligosaccharides and exopolysaccharides have ability to protect bacteria from adverse stress conditions, they might have practical application in food industry to protect health beneficial lactic acid bacteria in fermented food products and storage of starter cultures (Tieking and Ganzle, 2005).

Moreover, a number of other important roles of microbial exopolysaccharides have been reported recently (Liang and Wang, 2015). Various exopolysaccharides have been found to protect microorganisms from dehydration, phagocytosis, predation, bacteriophage attack, and from the adversary effects of antibiotics and toxic compounds (Roberts, 1996). Proper exploitation of lactic acid bacteria could be a faceable approach to produce versatile exopolysaccharide polymers for their practical applications (Frengova et al., 2002). Microbial EPSs have been found to display number of biological activities including antimicrobial, antiulcer, antitumor, immunomodulatory, and cholesterol lowering effect (Welman and Maddock, 2003).

Recently utilization of coconut waste water has been exploited in Thailand for the production of exopolysaccharide using an efficient strain L. confuses TISTR1498 leading to limit the coconut waste water supply as a waste to an extended amount (Seesuriyachan et al., 2011). Tieking and Ganzle (2005) reported the beneficial importance of lactic acid bacteria-derived exopolysaccharidesin dough and bread which may affect their technological properties in various aspects such as water absorption properties, rheological properties, stability during frozen state, loaf volume, and staling. In addition, polymers of exopolysaccharide have been successfully used in backing applications to improve the metabolic traits, flavor, texture and shelflife of bread (Tieking and Ganzle, 2005). A detailed overview on the industrial and pharmacological usefulness of microbial exopolysaccharides has been summarized in Figure 6. 


\section{Polysaccharides as microbicides}

It has been observed that a polymer group of sulfated polysaccharides has shown significant biological and functional properties (Ghosh et al., 2009). Since these sulfated polysaccharides as macromolecules display imitate patterns of sulfate substitution on glycosaminoglycans present in cell membranes, they have been found to be potent antiviral agents. Generally sulfated polysaccharides represent a complex polymer form of heterogeneous composition. Although chemical structure and activity relationship of sulfated polysaccharides have not been studied in detail, a number of these macromolecule even in crude forms have shown potent antiviral effect (Ghosh et al., 2009).

Microbicides are biocidal compounds or substances which reduce the infectivity of microbes, such asvirusesorbacteria. Generally microbicides are applied vaginally or rectally and protect the user from sexually transmitted infections caused by pathogenic fungi, viruses or bacteria. High molecular weight electrolytes, polyanions, are considered to be the most effective microbicides. A structural-activity relationship study of sulfated polysaccharides has confirmed the potent efficacy of these macromolecules as antiviral agents in terms of their ability to serve as microbicides (Ghosh et al., 2009).

Clinical trials offer justified approach of polysaccharides to be used as microbicides in future generations. These approaches include the synergistic or combinatory effect of various drugs especially in the initial inhibition of viral infection steps. Since lactic acid bacteria-derived sulfated polysaccharide confer safe and acceptable status on topical applications, strategies on developing next-generation microbicides using sulfated polysaccharides alone or in combination may give much better results on curing sexually transmitted diseases in terms of their antiviral or antimicrobial potency (Bollen et al., 2008; Kilmarx et al., 2008; Brache et al., 2007; Klasse et al., 2008). A microbicide (PC-815) developed via the combined mixture formulation of carrageenan and the nucleoside reverse transcriptase inhibitor MIV-150 has confirmed its efficacy as a nextgeneration microbicide (Woolfson et al., 2000; Malcom et al., 2005). However, successful application of these polysaccharide-based microbicide formulations has become a bloom and critical issue on these inhibitors for proper vaginal delivery system.

Exopolysaccharides as antiviral drugs and target

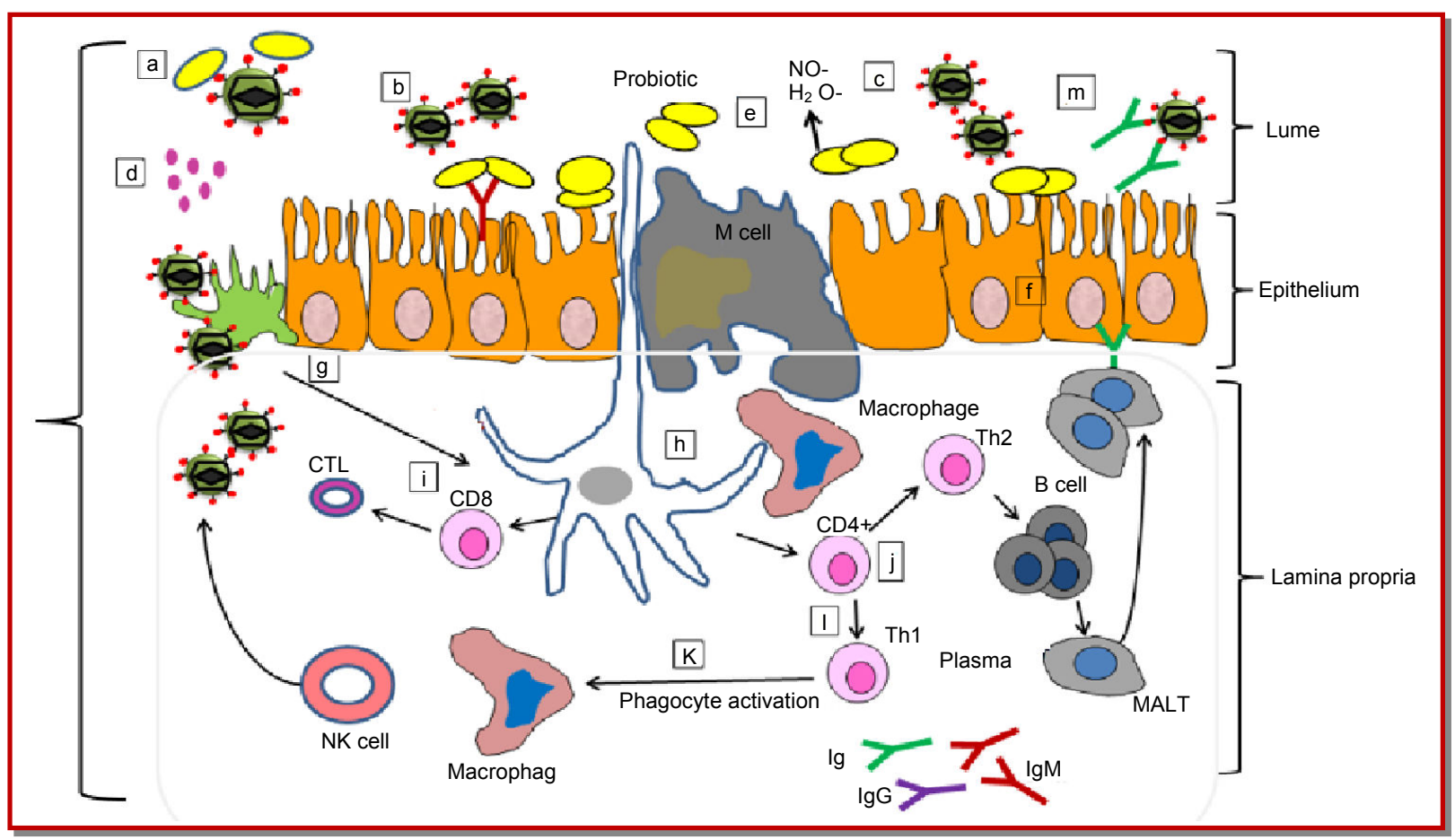

Figure 7: Schematic presentation of various antiviral mode of actions of probiotics including inhibition of virus by direct binding of viral particles (a); blockage of viral attachment by steric hindrance, blockage of cover receptor sites in non-specific manner (b); induction of mucosal regeneration thus binding virus particles and inhibit adherence to epithelial cells leading to inhibition of virus replication (c); production of antiviral compounds (d); antiviral effect through production of nitric oxide and dehydrogenase (e); promotion of normalization of mucosal barrier and enhancement in integrity of mucosal cells (f); epithelial immune response modulation (g); immune response modulation through macrophages (h); antiviral effect through activation of $\mathrm{CD}+\mathrm{T}$ lymphocyte differentiation into cytotoxic T lymphocytes (i); antiviral effect by phagocyte promotion through Th1 activation (j); through induction of B cells proliferation (k) and antiviral or viral neutralization effect through secretion of antibodies (l) [Lehtoranta, 2012] 


\section{modes of action}

Lactic acid bacteria have shown great potential in the prevention of severe gastrointestinal disorders in human beings and animals (Ohet al., 2010; Kumar et al., 2010). Although the mode of antiviral action of lactic acid bacteria has not beenelucidated in details, they have shown significant ability to inhibit viral infections and/or replicationeither directly or indirectly caused by respiratory, gastroenteric, murine, influenza, herpes and Newcastle disease viruses (Oh et al., 2010; Seo et al., 2010; 2012; Lange-Starke et al., 2014; Kassaa et al., 2014;). However, variations in the antiviral effect have been observed at species level based on the efficiency and biological properties of the test strain. Generally, mode of action of lactic acid bacteria as antiviral agents accomplished in four major steps which include i) adsorption hindrance, ii) internalization of virus in the cell, iii) production of antiviral substances, and iv) establishment of antiviral effect through immunomodulation or cross-talk. An outline of possible antiviral modes of action of lactic acid bacteria has been summarized in Figure 7.

Exopolysaccharides are known as potentially useful and biologically active polymer substances for medicinal and pharmaceutical uses due to their versatile biological properties. Liu et al., (2004) reported that polysaccharide may prevent viral infection through blockage of virus adsorption onto the host cells by interacting either with virus particles or with the host cell. This study confirmed that strong evidences on interaction of polysaccharide molecule and cell membrane should be occurred in order to confirm the proper blocking of receptor resulting in the adsorption of virus on the cell membrane (Liu et al., 2004). Among the tested polysaccharides, sulfated polysaccharides have shown potent ability to display antiviral effect (Oh et al., 2010). Inhibition of virus-cell adsorption onto the host cell is considered to be the first steps in viral infection process. It has been found that sulfated polysaccharides inhibit the virus-cell attachment and display antiviral effect against various types of viruses including hepatitis B virus, human cytomegalovirus, herpes simplex virus and influenza virus (Oh et al., 2010). Hence, in the current scenario of antiviral research, lactic acid bacteria and their derived polymers or polysaccharides are considered potential candidates in antiviral therapy to prevent or treat viral infections in both human and animals with remarkable efficacy and might have significant contribution in medicine and pharmaceutical industries in future (Oh et al., 2010).

An effective antiviral substance or compound has ability to prevent the cells from viral infections either directly by inactivating the virus particles or by interfering the replication cycle of virus. However, intracellular activity of any antiviral drug should be interpreted by excluding the possible capability of inactivating the virus extracellularly. A protein bound microbial polysaccharide showed potent ability to reduce the viral titer of herpes simplex virus-1 and herpes simplex virus-2 viruses (Eo et al., 2000). Although no precise antiviral mode of action of protein bound polysaccharide was defined, the significant antiviral activity against herpes simplex viruses might be attributed to the following reasons including disintegration of the entire herpes simplex virus particles, solubilization of the virus envelope, modification in chemical composition, protein degradation, or by covering the essential proteins of virus envelop (Eo et al., 2000). This study revealed that protein bound polysaccharide may exert its partial antiviral mode of action against herpes simplex virus-2 virus via binding the glycoproteins of herpes simplex virus-2 virus to protein bound polysaccharide which may interfere at the initial state of virus replication or release of any virions. Similarly the sulfated polysaccharides dextran sulphate and heparin showed remarkable antiviral activity via their interaction with virus particle attachment to the host cell (Bouhlal et al., 2011). In addition, other sulfated polysaccharides including pentosan, polysulphate, sulphated cyclodextrins, xylofuranan sulphate, ribofuranan sulphate and mannan sulphate have also been found to exhibit inhibition of viral replication process for herpes simplex virus, human cytomegalo virus and human immunodeficiency virus (Bouhlal et al., 2011).

Polymers of exopolysaccharide have shown potent antiviral effects, however, concerns have been raised on their acceptability due to their being relatively large molecular weight compounds and with a phenomenon that they block virus attachment, an unfavorable step in antiviral therapy, making them the molecules of uncertainty that they could pass through the different barriers of the body even cell membrane (Bouhlal et al., 2011). Large polymer molecules might be difficult to penetrate to certain extent when using in topical application for the treatment of specific cutaneous herpes simplex virus-1 viral infections, small oligosaccharide polymers such as dextran sulfate have ability to pass through easily from different body barriers. Also these oligosaccharides have shown better diffusion ability in blood when fed in the experimental rats with oral heparin ( $\mathrm{Li}$ et al., 2011). This study confirmed that oligosaccharide polymers such as dextrans possessing sulfate group might serve as natural alternatives in antiviral therapy leading to proper utilization of these inexpensive polysaccharides found abundantly in nature (Bouhlal et al., 2011). However, presence of other functional group other than sulfate might also have possibilities on the efficiency and antiviral properties of other types of polysaccharides.

It has been reported that polysaccharides such as 
carrageenan inhibit antiviral effect via inhibition of viral protein synthesis process only when it is present at early stage of virus particle entry (Bouhlal et al., 2011). In addition, although sulfated polysaccharides have shown their ability to reduce the number of viral plaques when used in crude form, the virions can internalized even at a 10-times higher concentration of carrageenan, necessary to block the early step of viral replication. This indicated that although virus internalization occurs, the viral replication can be blocked even in the absence of carrageenan confirming that perpetration was not solely acceptable. In contrast, lactic acid bacteria or lactic acid bacteria-derived polysaccharides show diverse range of biological properties. Recently, L. brevis KB290, a lactic acid bacterium with known immunomodulatory properties shown potent antiviral effect against influenza virus in experimental mice models (Waki et al., 2013). The results confirmed that KB290 when administered orally alleviated influenza virus-induced clinical symptoms which might be induced by long-lasting enhancement of interferon-aproduction and the augmentation of influenza virus-specific immunoglobulin-A production, suggesting that KB290 might have exopolysaccharide like component responsible for this antiviral effect (Waki et al., 2013). Also Kawase et al., (2010) reported that a Lactobacilli strain isolated from human intestinal tract prevented viral infection caused by influenza virus. An exopolysaccharide isolated from a probiotic strain L. bulgaricus OLL1073R-1 showed potent immuno -stimulatory effect (Makino et al., 2006; NishimuraUemura et al., 2003). Further, the effect of yogurt fermented with OLL1073R-1 on the reduced risk of respiratory infections was visualized in elderly following cohort studies (Nagai et al., 2011; Makino et al., 2010). It was found that fermented yogurt augmented the NK cell activity in the subjects who had lower NK cell activity, confirming that administration of exopolysaccharide containing yogurt might have potential role to prevent the infections of influenza virus since lymphocyte natural killer cells of innate immune system have crucial role in the early host defense against various viral infections (Makino et al., 2010; Viver et al., 2008).

Previously reported studies confirmed that firstgeneration antiviral drugs showed less potency in preventing the viral vaginal infection caused by human immunodeficiency virus- 1 transmitted virus. However, polysaccharides as second-generation drug alone or in combined formulation with other polysaccharide or drugs have shown broad range of antiviral spectrum leading to provide a sustainable antiviral therapy against vaginal pathogenesis (Ghosh et al., 2009). Lactic acid bacteria and lactic acid bacteria-derived polysaccharide specifically sulfated polysaccharides have several advantages over varied classes of synthetic and antibiotic antiviral substances having severe side effects. These polysaccharides have relatively low production cost, exert broad range of antiviral efficacy, show low range of toxicity, display low range of viral drug resistance, and show high lyophilicity, making them the candidates of promising antiviral drug discovery in near future with safe and widely acceptable levels which show precise modes of antiviral action.

\section{Future prospects}

Numerous studies have confirmed that lactic acid bacteria have potent ability to produce various types of chemically complex poly- and oligosaccharides. A plethora of information on the exopolysaccharide production ability of various Lactobacilli along with their diverse role in ecosystem have been well reviewed in the literature. However, efficacy on low amount of production by these Lactobacilli has limited their application as food grade additives. Influenced with these hurdles in exopolysaccharide production from lactic acid bacteria, studies on optimized parameters for efficient fermentation in combination with molecular and metabolic engineering techniques may help to achieve higher amount of exopolysaccharide biosynthesis by lactic acid bacteria. Moreover, a detailed information on the chemical and structural relativity relationship might help to provide microbial exopolysaccharides a new way for their practical applications in various desirable fields to be used as natural health promoters with diverse range of biological properties.

Although pivotal information at molecular level for some of the selected lactic acid bacteria on metabolic pathways involved in exopolysaccharide biosynthesis, gene sequencing with well-established chemical composition profile are available, this lacks the information on mechanisms of the secretion of microbial exopolysaccharides from bacterial cells as well as their relationship with genomic sequences and related enzymes responsible for exopolysaccharide production. Hence, future studies using advanced molecular techniques on this industrially-sound group of exopolysaccharides may result in the detailed view of the secretion of exopolysaccharides from microbial cells which may provide a scientifically innovative look leading to their enhanced production. In near future, gene expression level studies and molecular techniques can give new insights on enhanced production of microbial exopolysaccharides under controlled chemical environment leading to more functional and versatile exopolysaccharide production. Also the types of suitable methods can be a good target for obtaining optimized parameters for higher amount of exopolysaccharide production for microbial community. In this regards, exopolysaccharide producing lactic acid bacteria could be served as potent and natural microbial sources as efficient starter cultures with predictable 
chemical characteristics which may contribute significantly to develop innovative approaches for the enhanced production of various types of exopolysaccharides added with new and additional functional tracts of biological efficacy.

\section{Concluding remark}

Microbial exopolysaccharides have attracted huge attention in various industries especially in food, dairy and cosmetic industries due to their versatile functional and biological properties. Microbial exopolysaccharides have also been used in medicine and pharmaceutical industries making them important tools in drug delivery system and delayed drug released formulation. A number of selected microbial strains which produce exopolysaccharides efficiently have shown additional metabolic features, health beneficial effect and significantly affect texture, aroma, and shelflife of various food products. Apart from, exopolysaccharides have shown diverse range of industrial applications, they have been shown potent role in cellular recognition as well as found to protect the microbial cells from various adverse conditions such as osmotic stress, solid surface adhesion, protozoa predation, phagocytosis, phage attack, antibiotics or toxic compounds. Moreover, microbial exopolysaccharides have been successfully applied in the food industry as a bio-thickeners, viscosifers, as well as stabilizing and emulsifying agents. Since exopolysaccharides display multitude of biological and functional properties, when used as prebiotics, they can stimulate the function and growth of beneficial colon microflora thereby improving the host health system. Also exopolysaccharide polymers vary in their chemical nature, any specific functional property is positively correlated to the chemical structure of exopolysaccharides.

Exopolysaccharides of microbial origin display wide range of chemical diversity and functions and their production is not limited to a group of species. For example, they display monomeric compositions, linkage bonds and associated conjugates whereas the functions include intrinsic and applications. The major intrinsic functions of exopolysaccharides include morphological, structural and protective efficacy. However, exopolysaccharides can also be applied for human purposes in medical, cosmetic, food, pharma and dairy industries along with their efficacy in other industrial and environmental prospects. Although diverse range of microbial exopolysaccharides represent a huge amount of practical applications, specifically it is vital and necessity of these exopolysaccharide for human uses since they confer GRAS status as well as show cost effectiveness when used in environmental application for neutralizing toxic constituents. In non-industrial applications, cost of exopolysaccharide production has become a major limiting factor especially in case of bio-flocculation process. Apart from this, experimental efforts are still needed on searching efficient bacterial strains, enough capable to produce exopolysaccharides and exopolysaccharide-conjugates with higher yields that can meet their industrial need. In addition, use of costeffective and cheap substrate materials, optimization of fermentation condition in combination with genetic and metabolic engineering approaches might serve as effective tools for the enhanced production of functional exopolysaccharides for industrial applications.

Consequent inflation and inefficient downstream processing have also limited the exopolysaccharide production which has become a major hurdle in exopolysaccharide exploitation at industrial level. However, sufficient genetic information on exopolysaccharide biosynthesis and bioprocess manipulation strategies may assist to overcome such less exopolysaccharide production recovery. On the other hand, low awareness of consumers on exopolysaccharides also is a limiting factor for their commercial exploitation. Strict international laws and legislations have also affected significantly on the commercial usefulness of microbial exopolysaccharides. Since exopolysaccharides are known as "biofactories", these information reinforce the suggestions that complete commercial utilization of microbial exopolysaccharides can be achieved by gaining a detailed knowledge on their chemical nature, exopolysaccharide gene level expression studies, molecular organization of exopolysaccharide-related gene clusters, exopolysaccharide gene regulating factors, and the enzymes regulating the biosynthesis of microbial exopolysaccharides.

\section{References}

Badel S, Bernardi T, Michaud P. New perspectives for Lactobacilli exopolysaccharides. Biotechnol Adv. 2011; 29: 54 -66 .

Bae JW, Kim JJ, Jeon CO, Kim K, Song JJ, Lee SG, Poo HY, Jung $\mathrm{CM}$, Park $\mathrm{YH}$, Sung $\mathrm{MH}$. Application of denaturing gradient gel electrophoresis to estimate the diversity of commensal thermophiles. J Microbiol Biotechnol. 2003; 13: 1008-12.

Bae JW, Rhee SK, Park JR, Kim KH, Kim BC, Park YH. Monitoring population dynamics of Lactic acid bacteria during fermentation of Kimchi, a Korean traditional fermented vegetable, using community genome microarray. Appl Environ Microbiol. 2005; 71: 8825-35.

Banas JA, Vickerman MM. Glucan-binding proteins of the oral streptococci. Crit Rev Oral Biol Med. 2003; 14: 89-99.

Becker A, Vorholter FJ. Xanthan Biosynthesis by Xanthomonas Bacteria: An overview of the current biochemical and genomic data. In: Microbial production of biopolymers and polymer precursors, Norfolk, Caister Academic Press, 2009, 
pp 1-12.

Bello FD, Walter J, Hertel C, Hammes WP. In vitro study of prebiotic properties of levan-type exopolysaccharides from lactobacilli and non-digestible carbohydrates using denaturing gradient gel electrophoresis. Syst Appl Microbiol. 2001; 24: 232-37.

Bendiak B. An effective strategy for structural elucidation of oligosaccharides through NMR spectroscopy combined with peracetylation using doubly 13 C-labeled acetyl groups. Can J Chem. 80: 2002; 1032-38.

Bollen LJM, Kelly B, Kilmarx PH, Supaporn C, Cathy C, Punneporn W, Nucharee S, Jullapong A, Jordan WT, Janet MM. No increase in cervicovaginal proinflammatory cytokines after carraguard use in a placebo-controlled randomized clinical trial. J Acquir Immune Defic Synd. 2008; 47: 253-57.

Bouhlal R, Haslin C, Chermann JC, Colliec-Jouault S, Sinquin C, Simon G, Cerantola S, Riadi H, Bourgougnon N. Antiviral activities of sulfated polysaccharides isolated from Sphaerococcuscoronopifolius (Rhodophyta, Gigartinales) and Boergeseniellathuyoides (Rhodophyta, Ceramiales). Mar Drugs 2011; 9: 1187-09.

Brache V, Horacio C, R'egine SW, Robin AM, Juan CM, Kumar N, Salvatierra AM, Tejada AS, Cochon C, Forcelledo ML. Effect of a single vaginal administration of levonorgestrel in Carraguard ${ }^{\circledR}$ gel on the ovulatory process: A potential candidate for dual protection emergency contraception. Contraception 2007; 76: 111-16.

Broadbent JR, McMahon DJ, Welker DL, Oberg CJ, Moineau S. Biochemistry, genetics, and applications of exopolysaccharide production in Streptococcus thermophilus: A review. J Dairy Sci. 2003; 86: 407-23.

Buchholz K, Seibel J. Industrial carbohydrate biotransformations. Carbohydr Res. 2008; 343: 1966-79.

Cerning J, Bouillanne C, Landon M, Desmazeaud M. Isolation and characterization of excellular polysaccharides from slime-forming mesophilic lactic acid bacteria. J Dairy Sci. 1992; 75: 692-99.

Cerning J. Exocellular polysaccharides produced by lactic acid bacteria. FEMS Microbiol Lett. 1990; 87: 113-30.

Cote GL, Robyt FJ. Isolation and partial characterization of an extracellular glucansucrase from Leuconostoc mesenteroides NRRI B-1355 that synthesizes an alternating $(1 \rightarrow 6),(1 \rightarrow 3)$-aD-glucan. Carbohydr Res. 1982; 101: 57-74.

de Roos NM, Katan MB. Effects of probiotic bacteria on diarrhoea, lipid metabolism, and carcinogenesis: A review of papers published between 1988 and 1998. Am J Clin Nutr. 2000; 71: 405-11.

De Vos P, Garrity GM, Jones D, Krieg NR, Ludwig W, Rainey FA, Schleifer KH, Whitman WB (eds.). In: Bergey's manual of systematic bacteriology. 2nd ed. Volume 3. New York, Springer, 2009.

de Vuyst L, de Vin F, Vaningelgem F, Degeest B. Recent developments in the biosynthesis and applications of heteropolysaccharides from lactic acid bacteria. Int Dairy J. 2001; 11: 687-707.

deVuyst LD, Degeest B. Heteropolysaccharides from lactic acid bacteria. FEMS Microbiol Rev. 1999; 23: 153-77.

Donota F, Fontanaa A, Baccoua JC, Schorr-Galindo S. Microbial exopolysaccharides: Main examples of synthesis, excretion, genetics and extraction. Carbohyd Polym. 2012; 87: 951-62.

Duus JO, Gotfredsen $\mathrm{CH}$, Bock K. Carbohydrate structural determination by NMR spectroscopy: Modern methods and limitations. Chem Rev. 2000; 100: 4589-614.

Eo SK, Kim YS, Lee CK, Han SS.Possible mode of antiviral activity of acidic protein bound polysaccharide isolated from Ganoderma lucidum on herpes simplex viruses. J Ethnopharmacol. 2000; 72: 475-81.

Feldmane J, Semjonovs P, Ciprovica I. Potential of exopolysaccharides in youghurt production. Int $\mathrm{J}$ Biol Food Vet Agric Eng. 2013; 7: 424-27.

Figueroa C, Davila AM, Pourquie J. Lactic acid bacteria of the sour cassava starch fermentation. Lett Appl Microbiol. 1995; 21: 126-30.

Frengova GI, Simova ED, Beshkova DM, Simova ZI. Exopolysaccharides produced by lactic acid bacteria of kefir grains. App Microbiol. 2002; 45: 805-10.

Ganzle M, Michael G, Schwab C. Exopolysaccharide production by intestinal lactobacilli. In: Probiotics and prebiotics: Scientific aspects. Tannock GW (eds.). Norfolk, Caister Academic Press, 2005, pp 83-96.

Ghosh T, Chattopadhyay K, Marschall M, Karmakar P, Mandal P, Ray B. Focus on antivirally active sulfated polysaccharides: From structure-activity analysis to clinical evaluation. Glycobiol. 2009; 19: 2-15.

Gibson GR, Rastall RA. Gastrointestinal infections and the protective role of probiotics and prebiotics. Food Sci Technol. 2003; 23: 76-82.

Górska-Frączek S, Sandström C, Kenne L, Paściak M, Brzozowska E, Strus M, Heczko P, Gamian A.The structure and immunoreactivity of exopolysaccharide isolated from Lactobacillus johnsonii strain 151. Carbohydr Res. 2013; 28: 148 -53 .

Gorska S, Jachyrnek W, Rybka J, Strus M, Heczko PB, Gamian A. Structural and immunochemical studies of neutral exopolysaccharide produced by Lactobacillus johnsoni 142 . Carbohydr Res. 2010; 345: 108-14.

Gruter M, Leeflang BR, Kuiper J, Kamerling JP, Vligenthart JFG. Structural characterization of the exopolysaccharide produced by Lactobacillus delbrueckii subsp. bulgaricusrr grown in skimmed milk. Carbohyd Res. 1993; 239: 209-26.

Habibi N, Soleimanian S, Sheikhzeinoddin M. Exopolysaccharides produced by pure culture of Lactobacillus, Lactococcus and yeast isolated from Kefir grain by microtiter plate assay: Optimization and comparison. World Appl Sci J. 2011; 12: 742-50.

Harutoshi T. Exopolysaccharides of lactic acid cacteria for food and colon health applications. Biochemistry, genetics and molecular biology. In: Lactic acid bacteria: R and D for food, health and livestock purposes. Kongo M (ed). 2013, pp 22238 .

Hay ID, Rehman ZU, Ghafoor A, Rehm BHA. Bacterial 
biosynthesis of alginates. J Chem Technol Biotechnol. 2010; 85: 752-759.

Jolly L, Stingele F. Molecular organization and functionality of exopolysaccharide gene clusters. Int Dairy J. 2001; 11: 733-45.

Jolly L, Vincent SJ, Duboc P, Neeser JR. Exploiting exoployssacharides from lactic acid bacteria. Ant van Leeuwen. 2002; 82: 367-74.

Kang SA, Jang KH, Seo JW, Kim KH, Kim YH, Rairakhwada D. Levan: Applications and Perspectives. In: Microbial Production of Biopolymers and Polymer Precursors, Caister Academic Press, Norfolk 2009; pp 145-62.

Kanmani P, Yuvaraj N, Paari KA, Pattukumar V, Arul V. Productionand purification of a novel exopolysaccharide from lactic acid bacteriumStreptococcus phocae PI80 and its functional characteristics activity in vitro. Biores Technol. 2011; 102: 4827-33.

Kassaa AI, Hober D, Hamze M, Chihib NE, Drider D. Antiviral potential of lactic acid bacteria and their bacteriocins. Probiot Antimicrob Prot. 2014; 6: 177-85.

Kawase M, He F, Kubota A. Oral administration of lactobacilli from human intestinal tract protects mice against influenza virus infection. Lett App Microbiol. 2010; 51: 6-10.

Kilmarx PH, Kelly B, Supaporn C. A randomized, placebocontrolled trial to assess the safety and acceptability of use of carraguard vaginal gel by heterosexual couples in Thailand. Sex Trans Dis. 2008; 35: 226-32.

Kim CJ, Yoon SK, Kim HI, Park YH, Oh HM. Effect of Spirulina platensis and probiotics as feed additives on growth of shrimp Fenneropenaeus chinensis. J Microbiol Biotechnol. 2006; 16: $1248-54$.

Kim HG, Gim MG, Kim JY, Hwang HJ, Ham MS, Lee JM, Hartung T, Park JW, Han SH, Chung DK. Lipoteichoic acid from Lactobacillus plantarum elicits both the production of interleukin-23p19 and suppression of pathogen-mediated interleukin-10 in THP-1 cells. FEMS Immunol Med Microbiol. 2007; 49: 205-14.

Kim JD, Yoon JH, Park YH, Lee DW, Lee KS, Choi CH, Park WY, Kang KH. Isolation and identification of a lactic acid bacterial strain KJ-108 and its capability for deodorizing malodorous gases under anaerobic culture conditions. J Microbiol Biotechnol. 2003; 13: 207-16.

Kim JY, Park BK, Park HJ, Park YH, Kim BO, Pyo S. Atopic dermatitis-mitigate effects of new Lactobacillus sakei Probio 65 isolated from Kimchi. J Appl Microbiol. 2013a; 115: 517-26.

Kim PI, Jung MY, Chang YH, Kim SH, Kim SJ, YH Park. Probiotic properties of Lactobacillus and Bifidobaterium strains isolated from porcine gastrointestinal tract. Appl Microbiol Biotechnol. 2007; 72: 1103-11.

Kitazawa H, Ishii Y, Uemura J, Kawai Y, Saito T, Kaneko T, Itoh T. Augmentation of macrophage functions by an extracellular phosphopolysaccharide from Lactobacillus delbrueckii subsp bulgaricus. Food Microbiol. 2000; 17: 109-18.

Klasse PJ, Shattock R, Moore JP. Antiretorviral drug-based microbicides to prevent HIV-1 sexual transmission. Annu Rev Med. 2008; 59: 455-71.
Kleerebezem M, van Kranenburg R, Tuinier R, Boels IC, Zoon $\mathrm{P}$, Looijesteijn E, Hugenholtz J, de Vos WM. Exopolysaccharides produced by Lactococcus lactis: From genetic engineering to improved rheological properties? Ant Van Leeuwen. 1999; 76: 357-65.

Kodali VP, Das S, Sen R. An exopolysaccharide from a probiotic: Biosynthesis 427 dynamics, composition and emulsifying activity. Food Res Int. 2009; 42: 695-99.

Koh SK, Lee JE, Kim HW, Kim SS, Park YK, Park YH, Park YH, Koh KH. Identification and deacidification of lactic acid bacteria in Korean red wine. Food Sci Biotechnol. 2004; 13: 96 -99 .

Korakli M, Ganzle MG, Vogel RF. Metabolism by bifidobacteria and lactic acid bacteria of polysaccharides from wheat and rye, and exopolysaccharides produced by Lactobacillus sanfranciscensis. J Appl Microbiol. 2002; 92: 958-65.

Kralj S, Stripling E, Sanders P, van Geel-Schutten GH, Dijkhuizen L. Highly hydrolytic reuteransucrase from probiotic Lactobacillus reuteri strain ATCC 55730. Appl Environ Microbiol. 2005; 71: 3942-50.

Kumar AS, Mody K. Microbial exopolysaccharides: Variety and potential applications. In: Microbial production of biopolymers and polymer precursors. Norfolk, Caister Academic Press, 2009, pp 229-54.

Kumar VJR, Seo BJ, Mun MR, Kim CJ, Lee I, Kim H, Park YH. Putative probiotic Lactobacillus spp. from porcine gastrointestinal tract inhibit transmissible gastroenteritis coronavirus and enteric bacterial pathogens. Trop Anim Health Prod. 2010; 42: 1855-60.

Lamothe GT, Jolly L, Mollet B, Singele F. Genetic and biochemical characterization of exopolysaccharide biosynthesis by Lactobacillus delbrueckii subsp. bulgaricus. Arch Microbiol. 2002; 178: 218-28.

Landersjo C, Yang Z, Huttunen E, Widmalm G. (Eds)Book of Abstracts: First International Symposium on Lactic Acid Bacteria. 1st ed: Brussels 2001.

Lange-Starke A, Petereit A, Truyen U, Braun PG, Fehlhaber K, Albert T. Antiviral potential of selected starter cultures, bacteriocins and D-L-lactic acid. Food Eniviron Virol. 2014; 6: $42-47$.

Law A, Gu Y, Marshall V. Biosynthesis, characterization, and design of bacterial exopolysaccharides from lactic acid bacteria. Biotechnol Adv. 2001; 19: 597-625.

Le Costaouec T, Cerantola S, Ropartz D, Ratiskoi J, Sinquin C, Colliec-Jouault S, Boisset C. Structural data on a bacterial exopolysaccharide produced by a deep-sea Alteromonasmacieodii strain. Carbohyd Polym. 2012; 90: 49-59.

Leeflang BR, Faber EJ, Erbel P, Vliegenthart JFG. Structure elucidation of glycoprotein glycans and of polysaccharides by NMR spectroscopy. J Biotechnol. 2000; 77: 115-22.

Lehtoranta L. Probiotics and virus infections: The effects of Lactobacillus rhamnosus GG on respiratory and gastrointestinal virus infections. Academic Dissertation, Institute of Biomedicine, University of Helsinki, Helsinki, Finland, 2012.

Leo F, Hashida S, Kumagai D, Uchida K, Motoshima H, Arai I, 
Asakuma S, Fukuda K, Urashima T. Studies on a neutral exopolysaccharide of Lactobacillus fermentum TDS030603. J Appl Glycosci. 2007; 54: 223-29.

Liang TW, Wang SL. Recent advances in exopolysaccharides from Paenibacillus spp.: production, isolation, structure, and bioactivities. Mar Drugs 2015; 13: 1847-63.

Li JY, Jin MM, Meng J, Gao SM, Lu RR. Exopolysaccharide from Lactobacillus plantarum LP6: Antioxidation and the effect on oxidative stress. Carbohydr Polym. 2013; 98: 114752.

Liu J, Yang F, Ye LB, Yang XJ, Timani KA, Zheng Y, Wang YH. Possible mode of action of antiherpetic activities of a proteoglycan isolated from the mycelia of Ganoderma lucidum in vitro. J Ethnopharmacol. 2004; 95: 265-72.

Li YG, Ji DF, Zhong S, Lv ZQ, Lin TB, Chen S, Hu GY. Hybrid of 1-deoxynojirimycin and polysaccharide from mulberry leaves treat diabetes mellitus by activating PDX-1/insulin-1 signaling pathway and regulating the expression of glucokinase, phosphoenolpyruvate carboxykinase and glucose-6-phosphatase in alloxan-induced diabetic mice. J Ethnopharmacol. 2011; 134: 961-70.

Lynch KM, McSweeney PLH, Arendt EK, Uniacke-Lowe T, GalleS, Coffey A. Isolation and characterisation of exopolysaccharide-producing Weissella and Lactobacillus and their application as adjunct cultures in Cheddar cheese. Int Dairy J. 2014; 34: 125-34.

Madhuri KV, Prabhakar V. Microbial exopolysaccharides: Biosynthesis and potential applications. Oriental J Chem 2014; 30: 1401-10.

Maeda H, Zhu X, Omura K, Suzuki S, Kitamura S. Effects of an exopolysaccharide (kefiran) on lipids, blood pressure, blood glucose, and constipation. Biofact 2004; 22: 197-200.

Makino S, Ikegami S, Kano $H$, Sashihara $T$, Sugano $H$, Horiuchi H. Immunomodulatory effects of polysaccharides produced by Lactobacillus delbrueckii subsp. bulgaricus OLL1073R-1. J Dairy Sci. 2006; 89: 2873-81.

Makino S, Ikegami S, Kume A, Horiuchi H, Sasaki H, Orii N. Reducing the risk of infection in the elderly by dietary intake of yoghurt fermented with Lactobacillus delbrueckii subsp. bulgaricus OLL1073R-1. Br J Nutr. 2010; 104: 998-1006.

Malcom RK, Woolfson AD, Toner CF, Morrow RJ, McCullagh SD. Longterm, controlled release of the HIV microbicide TMC120 from silicone elastomer vaginal rings. J Antimicrob Chemother. 2005; 56: 954-56.

Martensson O, Oste R, Holst O. Lactic acid bacteria in an oatbased non-dairy milk substitute: Fermentation characteristics and exopolysaccharide formation. LebensmWiss Technol. 2000; 33: 525-30.

Mayo B, Aleksandrzak-Piekarczyk T, Fernandez M, Kowalczyk M, Alvarez-Martin P, Bardowski J. Updates in the metabolism of lactic acid bacteria. In: Biotechnology of Lactic Acid Bacteria. Mozzi F, Raya RR, Vignolo GM (eds). Iowa, Blackwell Publishing, 2010, pp 3-33.

Medrano M, Perez PF, Abraham AG. Kefiran antagonizes cytopathic effects of Bacillus cereus extracellular factors. Int J Food Microbiol. 2008; 122: 1-7.
Micheli L, Ucelletti D, Palleschi C, Crescenzi V. Isolation and characterization of a ropy Lactobacillus strain producing the exopolysaccharide kefiran. Appl Microbiol Biotechnol. 1999; 53: 69-74.

Mitsuoka T. Intestinal flora and aging. Nutr Rev. 1992; 50: 43846.

Mozzi F, Vaningelgem, Hebert EM, Van der Meulen R, Moreno MRF, Font de Valdez G, De Vuyst L. Diversity of heteropolysaccharide-producing lactic acid bacterium strains and their biopolymers. Appl Environ Microbiol. 2006; 72: 4431-35.

Nagai T, Makino S, Ikegami S, Itoh H, Yamada H. Effects of oral administration of yogurt fermented with Lactobacillus delbrueckii subsp. bulgaricus OLL1073R-1 and its exopolysaccharides against influenza virus infection in mice. Int Immunopharmacol. 2011; 11: 2246-50.

Navarini L, Abatangelo A, Bertocchi C, Conti E, Bosco M, Picotti F. Isolation and characterization of the exopolysaccharide produced by Streptococcus thermophilus Sfi 20. Int J Biol Macromol. 2001; 28: 219-26.

Nichols CM, Lardiere SG, Bowman JP, Nichols PD, Gibson JAE, Guezennec J. Chemical characterization of exopolysaccharides from Antarctic marine bacteria. Microb Ecol. 2005; 49: 578-89.

Nishimura-Uemura J, Kitazawa H, Kawai Y, Itoh T, Oda M, Saito T. Functional alternation of murine macrophage stimulated with extracellular polysaccharides from Lactobacillus delbrueckii ssp. bulgaricus OLL1073R-1. Food Microbiol. 2003; 20: 267-73.

Oh MH, Lee SG, Paik S. Antiviral activity of Lactobacillus spp. and polysaccharide. J Bacteriol Virol. 2010; 140: 145-50.

Oliver AE, Leprince O, Wolkers WF, Hincha DK, Heyer AG, Crowe JH. Non-disaccharide-based mechanisms of protection during drying. Cryobiol. 2001; 43: 151-67.

Orr D, Zheng W, Campbell BS, McDougall BM, Seviour RJ. Culture conditions affect the chemical composition of the exopolysaccharide synthesized by the fungus Aureobasidium pullulans. J Appl Microbiol. 2009; 107: 691-98.

Otero A, Vincenzini M. Extracellular polysaccharide synthesis by Nostoc strains as affected by $\mathrm{N}$ source and light intensity. J Biotechnol. 2003; 102: 143-52.

Park CW, Youn MS, Jung YM, Kim HI, Jeong YH, Lee HK, Kim HO, Lee IS, Lee SW, Kang KH, Park YH. New functional probiotic Lactobacillus sakei Probio 65 alleviates atopic symptoms in the mouse. J Med Food. 2008; 11: 405-12.

Park SB, Im M, Lee Y, Lee JH, Lim JH, Park YH. Effect of emollients containing vegetable-derived Lactobacillus in the treatment of atopic dermatitis symptoms: Split-body clinical trial. Ann Dermatol. 2014; 26: 150-55.

Park YH. Selection of a potential probiotics Lactobacillus strain and subsequent in vivo studies. Anton van Leeuwen. 2001; 80: 193-99.

Park YH, Baek IK, Kim KB, Kim CH, Woo KC. Effects of supplementary multiple probiotics or single probiotics on the performance, intestinal microflora, immune response of laying hens and broilers. Korean J Poultry Sci. 2010; 37: 51- 
62.

Patel AK, Michaud A, Singhania RR, Soccol CR, Pandey A. Polysaccharides from probiotics as food additives. Food Technol Biotechnol. 2010; 48: 451-63.

Patel A, Prajapati JB. Food and health applications of exopolysaccharides produced by lactic acid bacteria. Adv Dairy Res. 2013; 1: 1-7.

Patel S, Majumder A, Goyal A. Potentials of exopolysaccharides from lactic acid bacteria. Ind J Microbiol. 2012; 52: 3-12.

Peant B, LaPointe G, Gilbert C, Atlan D, Ward P, Roy D. Comparative analysis of the exopolysaccharide biosynthesis gene clusters from four strains of Lactobacillus rhamnosus. Microbiol. 2005; 151: 1839-51.

Rather IA, Seo BJ, Kumar VJR,Choi UH, Choi KH, Lim JH, Park YH. Isolation and characterization of a proteinaceous antifungal compound from Lactobacillus plantarum YML007 and its application as a food preservative. Lett Appl Microbiol. 2013; 57: 69-76.

Rather IA, Seo BJ, Kumar VJR, Choi UH, Choi KH, Lim JH, Park YH. Biopreservative potential of Lactobacillus plantarum YML007 and efficacy as a replacement for chemical preservatives in animal feed. Food Sci Biotechnol. 2014; 23: 195-200.

Rehm BHA. Bacterial polymers: Biosynthesis, modifications and applications. Nat RevMicrobiol. 2010; 8: 578-92.

Remminghorst U, Rehm BHA. Microbial production of alginate: Biosynthesis and applications. In: Microbial production of biopolymers and polymer precursors. Norfolk, Caister Academic Press, 2009, pp 13-42.

Rhee SK, Song KB, Kim CH, Park BS, Jang EK, Jang KH. Levan. Levan. In: Biopolymers. Steinbu"chel A, Baets SD, Vandamme EH (eds.). Weinheim, Wiley VCH, 2002, pp 35178 .

Ricciardi A, Clementi F. Exopolysaccharides from lactic acid bacteria: Structure, production and technological applications. Ital J food Sci.2000; 1:23-45.

Roberts IS. The biochemistry and genetics of capsular polysaccharide production in bacteria. Annu Rev Microbiol. 1996; 50: 285-315.

Robijin GW, Vanden Berg DJC, Haas H, Kamerling JP, Vilegenthart JFG. Determination of the structure of the exopolysaccharide produced by Lactobacillus sake 0-1. Carbohyd Res. 1995; 276: 117-136.

Ruas-Madiedo P, Tuinier R, Kanning M, Zoon P. Role of exopolysaccharides produced by Lactococcus lactis subsp. cremoris on the viscosity of fermented milks. Int Dairy J. 2002;12:689-695.

Sanchez JI, Martınez B, Guillen R, Jimenez-Daz R, Rodrıguez A. Culture conditions determine the balance between two different exopolysaccharides produced by Lactobacillus pentosus LPS26. Appl Environ Microbiol.2006;72:7495-7502.

Sartor RB. Therapeutic manipulation of the enteric microflora in inflammatory bowel diseases: antibiotics, probiotics, and prebiotics. J Gastroenterol.2004; 126:1620-1633.

Savadogo A, Ouattara CAT, Savadogo PD, Barro N, Ouattara
AS, Traore AS. Identification of exopolysaccharidesproducing lactic acid bacteria from Burkina Faso fermented milk samples. Afr J Biotechnol.2004;3:189-194.

Seesuriyachan P, Kuntiya A, Hanmoungjai P, Techapun C. Exopolysaccharide production by Lactobacillus confusus TISTR 1498 using coconut water as an alternative carbon source: The effect of peptone, yeast extract and beef extract. Songklanakarin J Sci Technol. 2011; 33: 379-87.

Seo BJ, Mun MR, Kumar VJR, Kim CJ, Lee IS, Chang YH, Park $\mathrm{YH}$. Bile tolerant Lactobacillus reuteri isolated from pig feces inhibits enteric bacterial pathogens and porcine rotavirus. Vet Res Commun. 2010; 34: 323-33.

Seo BJ, Rather IA, Kumar VJR, Choi UH, Moon MR, Lim JH, Park YH. Evaluation of Lecuconostoc mesenteroides YML003 as a probiotic against low-pathogenic avian influenza (H9N2) virus in chickens. J Appl Microbiol. 2012; 113: 163-71.

Seo WT, Kahng GG, Nam SH, Choi SD, Suh HH, Kim SW, Park YH. Isolation and characterization of a novel exopolysaccharide-producing Paenibacillus sp. WN9 KCTC 8951P. J Microbiol Biotechnol. 2001; 9: 820-25.

Sims IM, Frese SA, Walter J, Loach D, Wilson M, Appleyard K, Eason J, Livingston M, Baird M, Cook G, Tannock GW. Structure and functions of exopolysaccharide produced by gut commensal Lactobacillus reuteri 100-23. The ISME J. 2011; 5: $1115-24$.

Stingele F, Neeser JR, Mollet B.Identification and characterization of the eps (exopolysaccharide) gene cluster from Streptococcus thermophiles Sfi6. J Bacteriol. 1996; 178: 1680-90.

Tallon R, Bressollier P, Urdaci MC. Isolation and characterization of two exopolysaccharides produced by Lactobacillus plantarum EP56. Res Microbiol. 2003; 154: 705-12.

Tieking M, Ganzle MG. Exopolysaccharides from cereal associated lactobacilli. Trends Food Sci Technol. 2005; 80: 1679-84.

Tieking M, Kaditzky S, Valcheva R, Korakli M, Vogel RF, Ganzle MG. Extracellular homopolysaccharides and oligosaccharides from intestinal lactobacilli. J Appl Microbiol. 2005; 99: 692-702.

Tsuda H, Miyamoto T.Production of exopolysaccharide by Lactobacillus plantarum and the prebiotic activity of the exopolysaccharide. Food Sci Technol Res. 2010; 16: 87-92.

Uchida K. Nyuusannkinn no kouzou to kinntaiseibunn. In: Nyuusannkinn kennkyuu syuudannkai, (Eds). Nyuusannkinn no kagaku to gijutsu. Tokyo, Gakkai Syuppann Center, 1996, pp 59-88 (In Japanese).

Van Casteren, MR. (Ed.)Book of Abstracts: First International Symposium on Lactic Acid Bacteria. 1'sted: Brussels2001.

van Casteren WHM, de Waard P, Dijkema C, Schols HA, Voragen AGJ.Structural characterisation and enzymatic modification of the exopolysaccharide produced by Lactococcus lactis subsp. cremoris B891. Carbohyd Res.2000;327:411-22.

Van der Meulen R, Grosu-Tudor S, Mozzi F, Vaningelgem F, Zamfir M, De Vuyst L.Screening of lactic acid bacteria isolated from dairy and cereal products for exopolysaccharide production and genes involved. Int J Food Microbiol.2007;118:250-258. 
Van Hijum SAFT, Szalowska E, van der Maarel MJEC, Dijkhuizen L. Biochemical and molecular characterization of a levansucrase from Lactobacillus reuteri. Microbiol. 2004; 150: 621-30.

van Kranenburg R, Boels IC, Kleerebezem M, de Vos WM. Genetics and engineering of microbial exopolysaccharides for food: Approaches for the production of existing and novel polysaccharides. Curr Opin Biotechnol. 1999; 10: 498504.

van Kranenburg R, Marugg JD, van Swam II, Willem NJ, de Vos WM. Molecular characterization of the plasmid-encoded eps gene cluster essential for exopolysaccharide biosynthesis in Lactococcus lactis. Mol Microbiol. 1997; 24: 387-97.

Vandamme TF, Lenourry A, Charrueau C, Chaumeil JC. The use of polysaccharides to target drugs to the colon. Carbohydr Polym. 2002; 48: 219-31.

Vijayendra SVN, Babu SRS. Optimization of a new heteropolysaccharide production by a native isolate of Leuconostoc sp. CFR-2181. Lett Appl Microbiol. 2008; 46: 643-48.

Vincent SJF, Zwahlen C. Dipole-dipole cross-correlation at ${ }^{13} \mathrm{C}$ natural abundance: A structural tool for polysaccharides. J Am Chem Soc. 2000; 122: 8307-08.

Vinderola G, Perdigon G, Duarte J, Famworth E, Matar C. Effects of the oral administration of the exopolysaccharide produced by Lactobacillus kefiranofaciens on the gut mucosal immunity. Cytokine 2006; 36: 254-60.

Viver E, Tomasllo E, Baratin M, Walzer T, Ugolini S. Functions of natural killer cells. Nat Immunol. 2008; 9: 503-10.

Vorhölter FJ, Schneiker S, Goesmann A, Krause L, Bekel T, Kaiser O, Linke B, Patschkowski T, Rückert C, Schmid J, Sidhu VK, Sieber V, Tauch A, Watt SA, Weisshaar B, Becker A, Niehaus K, Puhler A. The genome of Xanthomonas campestrispv. campestris $\mathrm{B} 100$ and its use for the reconstruction of metabolic pathways involved in xanthan biosynthesis. J Biotechnol. 2008; 20: 33-45.

Waki N, Yajima N, Suganuma H, Buddle BM, Luo D, Heiser A, Zheng T. Oral administration of Lactobacillus brevis KB290 to mice alleviates clinical symptoms following influenza virus infection. Lett Appl Microbiol. 2013; 58: 87-93.

Welman AD, Maddox IS. Exopolysaccharides from lactic acid bacteria: Perspectives and challenges. Trends Biotechnol. 2003; 1 : 269-74.

Williams DL, Pretus HA, Browder IW. Application of aqueous gel permeation chromatography with in-line multi-angle laser light scattering and differential viscometry detectors for the characterization of natural product carbohydrate pharmaceuticals. J Liq Chromatogr. 1992; 15: 2297-309.

Woolfson AD, Malcolm RK, Gallagher R. Drug delivery by the intravaginal route. Crit Rev Ther Drug Carrier Syst. 2000; 17: $509-55$.

Wouters JTM, Ayad EHE, Hugenholtz J, Smit G. Microbes from raw milk for fermented dairy products. Int Dairy J.2002; 12: 91-109.

Yadav V, Prappulla SG, Jha A, Poonia A. A novel exopolysaccharide from probiotic Lactobacillus fermentum CFR 2195: Production, purification and characterization. Biotechnol Bioinf Bioeng. 2011; 1: 415-21.

Yamamoto Y, Nunome T, Yamauchi R, Kato K, Sone Y.Structure of an exocellular polysaccharide of Lactobacillus helveticus TN-4, a spontaneous mutant strain of Lactobacillus helveticus TY1-2.Carbohyd Res.1995; 275:319-332.

Yun JW. Fructooligosaccharides: Occurrence, preparation, and application. Enz Microb Technol. 1996; 19: 107-17.

Zajšek K, Goršek A, Kolar M. Cultivating conditions effects on kefiran production by the mixed culture of lactic acid bacteria imbedded within kefir grains. Food Chem. 2013; 139: 970-77.

\begin{tabular}{|l|l|l|}
\hline Author & Principal Contact & e-mail: \\
Info & Vivek K. Bajpai & vajpai04@yahoo.com \\
& $\begin{array}{l}\text { Kangmin Kim } \\
\text { Yong-Hal Kang }\end{array}$ & activase@jbnu.ac.kr \\
& sckang@daegu.ac.kr \\
& Feter@ynu.ac.kr \\
& First two authors contributed equally & \\
\hline
\end{tabular}




\section{Your feedback about this paper}

1. Number of times you have read this paper 0

2. Quality of paper
Excellent
O Good
Moderate
Not good

3. Your comments 